\title{
J(৫)
}

Received: 14.11 .2019

Accepted: 10.12 .2019

Published: 29.01 .2020

JOTS, 4/1, 2020: 50-97

\section{Eski Türk Yazıt ve El Yazmalarında Geçen Zıt Anlamlı İkilemeler Üzerine Yapısal ve Anlamsal Bir İnceleme}

\section{A Structural and Semantic Analysis on Antonym of Hendiadys in the Old Turkic Inscriptions and Manuscripts}

\author{
Ahmet KARAMAN \\ Inönü University (Malatya/Turkey) \\ E-mail: karamana00@gmail.com
}

This study includes an examination of the antonym of hendiadys in all old Turkish inscriptions and manuscripts. Firstly, the elements of the antonym of hendiadys identified will be examined one by one. This examination will be supported by etymological explanations when necessary. After examining the elements of the hendiadys in terms of structure, analysis will be started in terms of semantics. Then, structural and semantic analysis of the hendiadys will be conducted. In the end, the antonym of hendiadys of the examined structures will be questioned and their place in the hendiadys classification will be examined. In the study, both the elements that make up the hendiadys and the hendiadys will be explained together with their witnesses.

Key Words: reduplication duals/hendiadys, antonym of reduplication duals/hendiadys, vocabulary, Old Turkic Inscriptions and manuscripts. 


\section{J(G)}

\section{Giriş}

Hareketli bir yaratılışa sahip olan Türkler, tarih boyunca çok sık yer değiştirmiştir. Bunun bir sonucu olarak, Türk dili de farklı coğrafyalara yayılmıştır. Kökeni hakkında çeşitli tartışmaların bulunduğu eski Türk yazısı, en hacimli olanları VIII. yüzyıldan kalan ve II. Türk Kağanlığı'na ait yazıtlarla birlikte Çin'den Kafkasya'ya; Karadeniz'in kuzeyinden Balkanlara kadar uzanan topraklarda kullanılmıştır. Ötüken merkezli kurulan II. Türk ve Uygur Kağanlığı'ndan kalan resmi yazıtların yanında Çin'de, Dağlık Altay Cumhuriyeti'nde, Yenisey bölgesinde, Kırgızistan'da ve Moğolistan'da yer alan küçük yazıtlar taşlara işlenmiştir. Eski Türk yazısı, söz konusu yazıtlarda taşlar üzerine işlendiği gibi sonraki dönemlerde kâğıtlar üzerinde de kullanılmıştır. En meşhur örnekleri arasında Irk Bitig'in bulunduğu bu kâğıda yazılı metinler, eski Türk yazıtlarından bazı ses, yapı ve söz varlığı farklılıklarına sahiptir. Söz konusu metinler, özellikle içeriklerinin farklılığı nedeniyle, eski Türkçenin söz varlığının anlaşılmasında önemli bir role sahiptir.

Eski Türk yazısıyla yazılmış yazıt ve el yazmaları üzerine, geçmişten günümüze devam eden çalışmalar yürütülmektedir. Bu çalışmalar arasında ikileme konulu olanlar oldukça sınırlıdır. Metinlerin doğru okunması ve anlamlandırılması aşamasından başlayarak söz varlığı, sözcük türetimi, söz dizimi ve diğer bazı dil bilgisi ve anlambilim araştırmalarını gerektiren bir başka inceleme konusu da ikilemelerdir. Türkiye'de yapılan çeşitli araştırmalarda ikileme terimi için "kelime kosmaları. tekrarlar. ikileme-ikizleme. hağlam öhekleri ikilemeler. kosma takımları), tekrarlama, tekrar grubu, tekrar öbeği, eş çift tekrarl yapı sinıfları" gibi terimler kullanılmaktadır. Önerilen bu gibi terimlerin de incelenen yapıyı karşılamakta yetersiz kaldığğ görülmektedir. Özellikle içerisinde ‘tekrar, ikizlik, takım’ gibi sözcükleri içeren terimler, ikilemelerin ses ve yapı bakımından aynı sözcüklerin tekrar edilmesiyle oluştuğu algısına neden olmaktadır. Ayrıca bu tip terimler, ikilemelerin yalnızca bir türüne işaret edebilmektedir. İkileme terimi ise bünyesinde barındırdığı 'iki' algısı nedeniyle üçlü, dörtlü, beşli, altılı yapıları kapsamıyor görünmektedir. Buna karşın, uzun yıllar boyunca kullanımda olması ve zihinde 


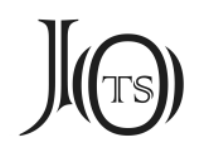

oluşturduğu net şemalar sayesinde araştırmacıların muhayyilesinde doğru sistemlere işaret ediyor olmasıyla kullanılabilir durumdadır. ${ }^{1}$

İkileme, anlatılmak istenen duygu ve düşüncelerin aktarım gücünü artırmak, anlatımı / anlamı kolaylaştırmak / pekiştirmek, kavramı zenginleştirmek, sözü güzelleştirmek gibi amaçlarla, aynı sözcüğün tekrar edilmesi veya eş, yakın yahut zit anlamlı ya da sesleri birbirine benzeyen iki veya daha fazla sözcüğün art arda yahut aralıklı olarak kullanılmasıdır. İkilemeyi oluşturan sözcükler arasında, anlam ya da ses yönünden benzerlikler bulunmaktadır. İkilemeler en az iki sözcükten teşekkül etmektedir. İkileme teriminin kendisinden kaynaklanan bir yanılsama, bu tip yapıların iki sözcükten oluşmuş olduğu düşüncesidir. Oysa böyle bir zorunluluk olmayıp unsur sayısı esnektir. Yapılan tanımlamalarda yanılgıya düşülen bir diğer husus ise ikilemeyi oluşturan unsurların art arda gelme zorunluluğudur. Yine böyle bir şart yoktur. İkileme unsurları arasına çeşitli tür ve görevlerde sözcük girebilir.

Anlamın pekiştirilmesi ve zenginleștirilmesi bir yana, dillerin, dış dünyada yer alan sonsuz sayıdaki varlığı karşılamak üzere başvurdukları yöntemler açısından bakıldığında, ikilemeler daha dikkat çekici bir noktada yer almaktadır. Çünkü kimi ikilemeleri oluşturan sözcükler, zaman içerisinde ayrı ayrı karşıladıkları anlamları yitirerek, tek ve yeni bir anlama bürünebilmektedir. Böylece dil, evrendeki sayısız varlığa, bünyesindeki malzemeyi kullanarak yeni karşlıklar bulma imkânına kavuşmaktadır. Bu tip anlam değişmeleri, soyutlaşmalar ve mecazî kullanımlar, bir dilin ne denli işlendiğini, olgunlaştığını göstermektedir. Nitekim bu çalışmada incelenen malzemenin bir kısmının 8. yüzyıldan kalma yazıtlar olduğu düşünüldüğünde, daha o dönemden Türk dilinin olgunluğu gözler önüne serilmektedir. Dahası, ilişkide olduğu dillere oranla, Türk dili daha fazla ikilemeyi bünyesinde barındırmaktadır. İkilemelerin bir başka fonksiyonu da hiç şüphe yok ki sözü güzelleştirmesidir. Özellikle aralarında ses benzerliği bulunan ikilemeler, konuşma ve günlük yazı dilinde dahi ahenkli bir söyleyişi mümkün kilmaktadır.

1 İkileme terimi için kullanılan adlandırma önerileri için ayrıca bk. Hirik 2018. 


\section{J(৫)}

İkilemelerin nasıl tasnif edilmesi gerektiği tartışmalı bir konudur. Yapılan ikileme konulu çalışmalarda, çeşitli sınıflama ölçütleri kullanılmıştır. Bu tasnifler anlamsal ve yapısal olarak düzenlenmiştir. İkilemeler bir dilin söz varlığında önemli fonksiyonlar üstlenmektedir. Bu noktada ikilemeler muhakkak bağlam içerisindeki yerleriyle incelenmeli ve tasnifler arasında mutlaka anlamsal bir s1nıflandırma bulunmalıdır. Eş, yakın ve zıt anlamlı sözcüklerden oluşan ikilemelerin ayrı ayrı tespit edilmesi önemlidir.

Zit anlamlı sözcüklerden oluşan ikilemeler, ikileme türleri içerisinde farklı bir yer tutmaktadır. Türkçenin dış dünyadaki sınırsız varlı̆̆ı karşılamakta kullandığı araçlardan olan sözcükler arası anlam ilişkileri ve ikilemeler bu noktada kesişmektedir. Yapılacak bu çalışmada, tüm eski Türk yazıt ve el yazmalarında kullanılan zıt anlamlı ikilemeler, öncelikle unsurları açısından incelenecektir. İkilemeyi meydana getiren unsurlar, gerektiği noktada etimolojik açılamalarla desteklenerek yapısal açıdan incelenecektir. Elbette burada amaç sözcüklere tam bir etimolojik izah getirmek değildir. Maksat ikilemelerin anlaşılabilmesi açısındandır. Sonrasında ikilemeyi oluşturan sözcüklerin ayrı ayrı anlamları üzerinde durulacaktır. Ayrıca unsurlar arasındaki ses benzerlikleri üzerinde durulacaktır. $\mathrm{Bu}$ itibarla, incelenen ikilemelerin ses benzerliğiyle mi yoksa anlam ilgisiyle mi oluştuğu tespit edilecektir. Son olarak, edinilen bilgiler ışı̆̆ında, ikilemelerin yapısal ve anlamsal çözümlemelerine geçilecektir. Sınıflandırma yapılırken, ikilemeyi oluşturan unsurların bir araya gelirken aralarında kurulan zıtlık ilgisinin mi yoksa oluşmuş ikilemenin karşıladığı anlamın mı dikkate alınacağı belirsizdir. Yapılacak olan bu çalışmada, tümevarım yöntemiyle bu belirsizliğin giderilmesine de çalışılacaktır. İkilemeyi oluşturan sözcükler, yazıt ve el yazmalarındaki örnek kullanımlarıyla verilecektir. Böylece, sözcüklerin farklı tanıklamaları rahatlıkla görülebilecektir. Üzerinde durulan zıt anlamlı ikilemelerin, varsa eski Türkçe döneminin diğer iki evresini oluşturan eski Uygur ve Karahanlı Türkçesi metinlerindeki kullanımları da verilecektir. Böylelikle metinler arası yapı ve anlam karşılaştırması yapılmış olacaktır.

Çalışma, iki ana temel üzerinde şekillenecektir. Bu iki ana bölüm, zıt anlamlı ikilemelerin sözcük türüne göre ayrılması biçimindedir. İlk bölümde ad soylu 


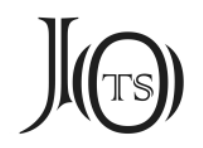

sözcüklerden oluşan ikilemeler, ikinci bölümde ise eylemlerden oluşan ikilemeler incelenecektir. ${ }^{2}$

\section{Ad Soylu Sözcüklerle Kurulan Zit Anlamlı İkilemeler}

\section{1. açsılk tosık}

'Tok olma, yiyecek bir şeye ihtiyacı olmama' durumunun zıttı olan aç sözü, II. Türk Kağanlığı'ndan kalan Bilge Kağan yazıtının doğu 38. ve Kırgızistan yazıtlarından Talas-13 yazıtının 3. satırında tanıklanmıştır:

[...] türük bodun aç erti [...] “Türk halkı aç idi” (Aydın 2017: 94)

[...] ay(a)l(a)rımda (a)t aç: ök(ü)z (a)ç [...] “Akrabalarımda at aç, öküz aç!” (Alimov 2014: 133)

Açsık sözcüğü ise, eski Türk yazısıyla yazılmış yazıt ve el yazmalarında, yalnızca Köl Tegin yazıtının güney 8. ve Bilge Kağan yazıtının kuzey 6. satırında geçmektedir:

[...] türük bodun tokurkak sen açsık tosık ömez sen bir todsar açsık ömez sen [...] "(Ey) Türk halkı sen toksun. Açlık (ve) tokluğu düşünmezsin. Bir doyarsan açlığı düşünmezsin.” (Aydın 2017:

49)

[...] türük bodun tokurkak sen açsar (açslk?) tosık ömez sen bir todsar açsık ömez sen [...] “(Ey) Türk halkı sen toksun. Açlık (ve) tokluğu düşünmezsin. Bir doyarsan açlığı düşünmezsin.” (Aydın 2017: 76)

Açsık sözcüğünü açılamakta, üç ihtimalden söz edilebilir. Köl Tegin yazıtının güney 8. satırındaki her iki örnek de 4 \入 $\$$ biçiminde; Bilge Kağan yazıtının

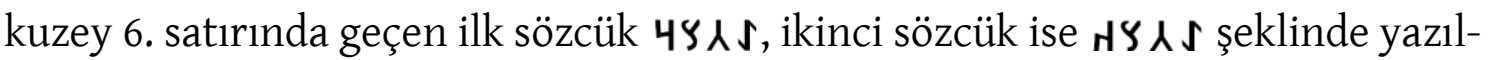
mıştır. Eski Türk yazısında kalın sıradan seslerle kullanılan ' $K$ ' harfi ile kalın s1radan seslerle kullanılan ' $R$ ' harfinin yazımı birbirine karıştırılacak derecede benzerdir. Orhon yazıtları her ne kadar kağanlığın denetiminde diktirilmiş olsa da bu iki harf birbiriyle karıştııılmış olabilir. Bu durumda Bilge Kağan yazıtındaki açsar ifadesi açsık olarak düzeltilmelidir. Zira tosık sözcüğü her iki yazıtta da HS> $\delta$ biçimde yazılmıştır. Aç- ve to- eylemleri, eylemden ad türeten $\{$-sIk\} ekini

2 Bu yazıda incelenen zıt anlamlı ikilemeler Aydın-Karaman 2019'a dayanmaktadır. 


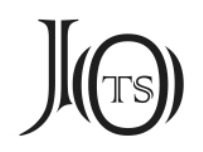

almıştır. Açsık sözcüğü, Eski Uygur Türkçesinde de tanıklanmıştır. Açsık sözcüğünün anlamı ise TT'nin analitik indeksinde 'karnı aç' biçiminde sıfat olarak verilmiştir (Bang-Gabain 1929: 134). CAFEROĞLU da açsık sözcüğüne 'acıksama, açlık, acıkma' karşılıklarını vermiştir (2015: 2).

Eğer sözcük açsık değil de açsar olarak düzeltilecek ise satırların anlamı:

[...] türük bodun tokurkak sen açsar tosık ömez sen bir todsar açsık ömez sen [...] "(Ey) Türk halk1 sen toksun. Acıkırsan tokluğu düşünmezsin. Bir doyarsan (da) açlığı düşünmezsin.”

biçiminde olacaktır. Bu durumda burada bir ikileme oluşumundan söz edilemez. Üçüncü bir ihtimalde ise KT G8'deki ifade açsık tosık biçiminde BK G6'daki ifade ise açsar tosık olarak alınabilir. Söz konusu bu üç önermeden en uygun olanı ilk önermedir. Gerek açsı sözcüğü ile tosı sözcüğü arasında ses benzerliğinin bulunması gerekse de sözcüklerin aynı eki alarak kalıplaşmış oldukları göz önüne alınarak, bu yapı açsık tosık biçiminde bir ikileme kabul edilmelidir. ${ }^{3}$

Tosık sözcüğü, yukarıda da ifade edildiği üzere, to- eyleminden türemiştir. Yazıt ve el yazmalarında to- sözcüğünden türemiş dört sözcük bulunmaktadır. Bunlar; Tonyukuk 1 yazıtının güney birinci satırında ve Tes yazıtının kuzey beşinci satırında geçen tok ile KT G8, BK K6'da geçen tod-, tokurkak ve tosık sözcükleridir.

Açsık tosık ikilemesinin her iki unsuru da eylemden oluşmuş ve aynı eki almıştır. İkilemenin ses benzerliği aynı eki almaları ile sağlanmıştır. İkilemenin anlam dünyası ise hayli geniştir. İfade, mecazî bir anlam içermektedir. İlgili satırlarda bir serzeniş, bir tepki sezilmektedir. illk türük bodun tokurkak sen ifadesiyle, Türk halkının hali hazırda tok olduğu vurgulanmıştır. Daha sonra açsık tosık ömesözüyle, geçmişteki açlık çekilen ibretlik zamanların artık hatırlanmadığı, bugünün kıymetinin bilinmediği ifade edilmiştir. Aynı zamanda bu kullanımla, toklukla geçen yani sıkıntısızca yaşanan günlerin ebediyen süreceğinin düşünülerek yarın gelebilecek zor günlere, açlığın hüküm sürebileceği zamanlara hazırlık yapılmadığı da sitemkâr bir ifadeyle vurgulanmıştır. Açlığın tokluğun düşünülme-

\footnotetext{
3 Açsık için ayrıca bk. ED 31a.
} 


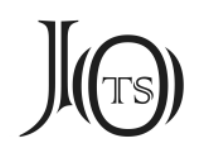

mesinden kasıt, halk tarafından dünün değerinin bilinmemesi; yarının kaygıs1nın dikkate alınmamasıdır. Nitekim ilgili satırların devamında, dünün kıymetini bilip, yarının derdini sırtında taşıyarak halkı besleyen kağanın sözüne itibar etmeyip şuursuzca hareket eden halkın başına gelen acılar anlatılmıştır. Birbirinin karşıtı olan açsık ve tosık sözcükleri, bir araya gelerek, ikileme formunda çok daha derin anlamları karşılamıştır. Anlamsal açıdan yapılacak bir tasnifte, hem unsurlarının birbirlerinin karşıtı olmaları hem de ortaya çıkan yeni anlamın da zıtlık içermesinden ötürü, açsık tosık ikilemesi zıt anlamlı ikilemeler kapsamında değerlendirilmelidir. Çünkü ikilemenin içerdiği 'açlığı ve tokluğu düşünmemek, dünü ve yarını dikkate almamak, geçmişin rahatlığının ve geleceğin olası sıkıntılarının akledilmemesi' anlatımları da karşıtlık ifade etmektedir.

\section{2. antlig antsiz}

And/ant sözcüğü, yazıt ve el yazmaları içerisinde geçmemektedir. Eski Uygur ve Karahanlı Türkçesi metinlerinde ise tanıklanmıştır. 'Yemin, söz' olarak anlamlandırılabilecek and / ant sözcügüne \{+lIg\} isimden isim yapma ekinin getirilmesiyle türetilmiş olan antlig ve yine isimden isim yapan $\{+$ sIz\} ekinin getirilmesiyle oluşan antsız sözcüğü ise yazıt ve el yazmaları içerisinde yalnızca Yenisey bölgesi yazıtlarında geçmektedir. Bu itibarla, her iki sözcük de birer ileri öge niteliği taşımaktadır. Begre yazıtının 8. satırında:

antlıg adaşım a antsızda edgü eş̧im e adrldım a "Ant içtiğim yoldaşım, ant ile bağlı olmayan iyi eşimden, dostumdan ayrıldım.” (Aydın 2019: 70-71)

denilmektedir. Antlıg sözcüğü, Orta Asya kavimlerinde ortak olarak görülen ve iki kişinin birbirine herhangi bir nedenle yemin etmeleri sonucu, birbirlerine bu yeminle / antla bağlanmış olmalarını ifade etmektedir. Bu ant sayesinde, insanlar arasında sarsılmaz bir bağ kurulmaktadır. ${ }^{4}\{+1 \mathrm{lg}\}$ eki eklendiği şeyin varlığına, $\{+$ sIz $\}$ eki ise yokluğuna işaret etmektedir. Bu itibarla antsız sözü de böyle bir yeminle bağlanmamış olmayı ifade etmektedir. Bir bakıma, \{+sIz\} eki $\{+$ lIg $\}$ ekini alan aynı sözcüğün karşıtını türetmektedir. Yalnızca ekler üzerinden düşünüldüğünde dahi bu iki sözcüğün zıtlık ifade ettiği anlaşılmaktadır. Dolaysıyla,

\footnotetext{
4 Ant için ayrıca bk. Röhrborn 1977: 145b; Roux 2011: 22.
} 


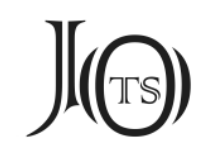

antlıg antsız ikilemesi hem unsurları hem de ikilemenin oluşturduğu anlam itibariyle zıt anlamlı bir yapıdır. Burada dikkat çeken bir başka husus da ikilemelerin art arda sıralanması zorunluluğunun olmamasıdır. Antlıg antsız sözcükleri burada birer sıfattır ve araya doğal olarak antlıg sözcüğünün nitelediği ad olan adaş sözü girmiştir. Antlıg antsız ikilemesinde ses benzerliği, aynı ant kökünün kullanılmış olmasıyla sağlanmıştır. İkileme, iki türemiş sözcükten oluşmuştur ve ikilemenin unsurları farklı ekleri almıştır.

\section{3. az üküş}

$A z$ sözcüğ̈̈ eski Türkçe döneminin her üç evresinde de çok sık olarak kullanılmıştır. Az sözü eski Türkçede farklı anlamları karşılayan sesteş kök niteliğindedir. ${ }^{5}$ Burada sözü edilen $a z$, üküşsözcüğünün karşıt anlamlısı olup miktar bildirmektedir. Üküş sözcüğü de eski Türkçenin üç evresinden kalan metinlerde de sıkça kullanılmıştır ve miktar bildirmektedir. Miktar açısından az olanın karşıtı çok olandır. Eski Türk yazısıyla yazılmış yazıt ve el yazmaları içerisinde:

\section{[...] az bodunug üküş kıltım [...] “Az halkı çoğalttım.” (Aydın 2017: 50, 60, 66, 89) [KT G10, KT D29, BK K7, BK D24]}

[...] çıgañıg bay kıltı azıg üküş kıltı [...] "Yoksulu zengin etti, az (halkı) çoğalttı." (Aydın 2017: 84) [BK D14]

yawız bat biz azıg üküşüg körtüg [...] "kötü (ve) zayıf (durumdayız). Azı (ve) çoğu gördün.” (Aydın 2017: 124) [O D7]

ifadeleri yer almaktadır. II. Türk Kağanlığı'nın hüküm sürdüğü Orta Asya bozkırında, diğer yönetimlerde olduğu gibi, Türk devletinde de nüfusun çok olması istenilen bir durumdu. Dönemin Türk kağanları da milletinin çokluğuyla övünmekteydi. Bu anlayış, yukarıda verilen satırlarda görüldüğü üzere, kağanın kendini övme biçimine de yansımıştır. $O$ dönemde de her dönemde olduğu gibi nüfusun niceliksel çokluğuna nitelik eklendiğinde devletin gücü ve kalıcılığı artmaktaydı. Eski çağlarda hüküm sürmüş güçlü devletlerin hemen tamamında, insan kaynağı yeterli oranda olmuştur. Bu durum modern çağlarda dahi kısmen

5 Az sözcüğünün farklı anlamları için bk. Karaman 2019. 


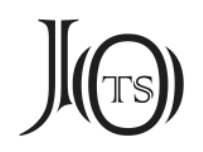

devam etmektedir. Ongi yazıtındaki kullanım ise daha dikkat çekicidir. Okunamayan satırlar nedeniyle anlam biraz muğlak olsa da burada 'azı' ve 'çoğu' görmekten kastedilen, fakirlik/zenginlik veya sayıca azlık/çokluk olmalıdır. Satırın devamından kestirilebilen ise kendilerinin az, düşmanlarının ise çok olmasına rağmen mücadeleden kaçınılmadığı vurgusudur. Burada, kendilerini az, düşmanlarını çok sayıda gördükleri halde, sefer düzenledikleri anlatılmıştır. İfade edilmek istenen bu sözler, ikileme kullanımıyla dikkat çekici hale bürünmüştür.

İlgili satırlarda ikilemelerin arasına, az sözcüğünün nitelediği bodun sözcüğg̈ girmiştir. İkileme herhangi bir ses benzerliği taşımamaktadır. İkilemenin unsurları, anlam ilgisine göre bir araya getirilmiştir. İkilemenin unsuru olan iki sözcük de herhangi bir ek almamıştır. Az üküş ikilemesi, hem unsurlarının bir araya geliş mantığıyla hem de içerdiği anlam açısından, ikileme tasnifinde çok açı bir biçimde zıt anlamlı ikilemeler kapsamına alınmalıdır. Bu ikileme, eski Uygur ve Karahanlı Türkçesi metinlerinde de geçmektedir. Yazıt ve el yazmaları içerisindeki anlam ve fonksiyon aynen korunmuştur:

[...] azh üküşli buşınıı aruşı [...] (Zieme 1985: 29)

[...] süsi az öküşin yağı bilmese [...] (Arat 1979: 249/2350)

[...] kiçe az öküşüg ne bilgey aça [...] (Arat 1979: 250/2361)

[...] sana az öküş ney törü ķlsalar [...] (Arat 1979: 445/4432)

\section{4. bilir bilmez / körür körmez}

Kör- sözcügü, yazıt ve el yazmalarında 'itaat etmek', 'tâbi olmak' gibi derin anlatımların yanında gerçek anlamıyla 'görmek, bakmak' karşlığında da kullanılmıştır. Kör- eylemine eklenen $\{-(\mathrm{X}) \mathrm{r}\}$ sıfat-fiil eki, bu yetinin yeterliliğini ifade eden körür sözcüğüne işaret etmektedir. Yine kör- eylemine $\{-\mathrm{mAz}\}$ sıfat-fiil ekinin getirilmesiyle oluşan körmez sözü ise bu yetinin yetersizliğini ifade etmektedir. Birbirinin zıddı olan anlamları karşılayan körür körmez yapısına benzer bir diğer ifade ise bilir bilmez yapısıdır. Bil- eylemi yazıt ve el yazmalarında çok sık tanıklanan bir sözcüktür. Sözcük, 'bilmek, anlamak, kavramak' anlamlarını karşılamaktadır. Ayrıca, E 32 numaralı Uybat III yazıtının 3. satırında geçen tike bilir erti 'dikebilir idi' ifadesinde yeterlik bildirmektedir. Bil- eylemine getirilen $\{-(\mathrm{X}) \mathrm{r}\}$ 


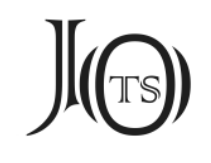

ve $\{-m A z\}$ sıfat-fiil ekiyle türetilmiş olan bilir ve bilmez sözcükleri de karşıt anlatımlara sahiptir. Köl Tegin yazıtının kuzey 10. satırında:

[...] körür közüm körmez teg bilir biligim bilmez teg boltı [...] “Görür gözüm görmez gibi, bilir bilgim bilmez gibi oldu." (Aydın 2017: 67)

ifadeleri yer almaktadır. Köl Tegin'in kahramanlıklarının anlatıldığı önceki satırlardan sonra, kuzey 10'da Bilge Kağan tarafından Köl Tegin'in öldüğü dile getirilmektedir. Pek çok açıdan halk için ne denli önem arz ettiği vurgulanan Köl Tegin öldüğünde, Bilge Kağan tek başına düşüncelere dalmaktadır. Bilge Kağan, kardeşinin hayatını muhayyilesinde yeniden anımsamaktadır. Onun ölmesi yüzünden, gören gözleri görmez, kavrayan aklı ise kavramaz olmuştur. Gören gözlerin görmez; kavrayan aklın kavramaz olması mecazlı bir anlatımdır. Yaşanan üzücü olaylar karşısında, insanın ne derece kötü hâle düştüğünü anlatan bu ifade biçimleri, çağdaş Türk lehçelerinde de kullanılmaktadır. Bilge Kağan, kardeşinin ölümü karşısında içinde bulunduğu durumu karşıt anlamlı sözcüklerle kurulmuş ikileme yapılarıyla ifade ederek sözüne etkileyicilik katmıştır. Her iki yapı da simgesel bir anlatıma sahiptir. İfadelerin genelinde bir yeterlik anlamı söz konusudur. Her iki ikilemenin de teşkilinde aynı köklerin kullanılmış olması ses benzerliğini sağlamıştır. Aynı köke eklenen $\{-(\mathrm{X}) \mathrm{r}\}$ ve $\{-\mathrm{mAz}\}$ ekleri birbirinin karşıt anlamlısı olan sözcükler türetmektedir. Bu itibarla aynı fonksiyonu karşılayan körür körmez ve bilir bilmez ikilemeleri zıt anlamlı ikilemeler tasnifi içerisinde yer almalıdır.

\section{5. çıgañ bay}

Zengin sözcüğünün karşıt anlamlısı olan çıgañ sözcüğü, büyük kağanlık yazıtlarından başka Irk Bitig 30'da geçmektedir:

çıgañ : er : oglı : kazgançka : barmış [...] "Yoksul bir adamın oğlu para kazanmaya gitmiş.” (Y1ldırım 2017: 40)

denilmektedir. Sözcüğün, yazıt ve el yazmaları içerisinde ikileme formu dışındaki tek kullanımı budur. Yazıtlarda bu sözcük her kullanımında ikileme yapisı içerisindedir. Sözcük, KT G10 ve BK K7'de geçen eş anlamlı yok çıgañ ve zit 


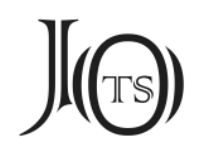

anlamlı çıgañ bay ikilemelerinin unsuru olarak kullanılmıştır. Eski Uygur ve Karahanlı Türkçesi metinlerinde sözcüğün çıgay biçimi kullanılmıştır. Bay sözcüğü, büyük kağanlık yazıtlarında yalnızca çıgañ sözcüğüyle birlikte ikileme formu içerisinde yer almıştır. Sözcük, Yenisey bölgesi yazıtlarından Çaa-Höl V yazıtının 1. satırında kişi adı parçası olarak 'tüz bay küç bars külüg' '(Ben) Tüz Bay Küç Bars Külüg('üm)." (Aydın 2019: 85); Kara-Yüs I yazıtının 6. satırında sıfat olarak 'bay apam yarayu "zengin ceddim yurda yararlı (işler yaptı.)" (Aydın 2019: 132) ve Novosyolovo yazıtının 2. satırında bay bar ikilemesinin unsuru olarak "bay bar e<r>tim “Zengin (ve) varlıklı idim' (Aydın 2019: 231) biçiminde kullanılmıştır. Sözcük, Uygur Kağanlı̆̆ı'ndan kalan Suci yazıtının 5. satırında da bay bar ikilemesinin bir unsuru olarak 'bay bar ertim' (Aydın 2018: 87) biçiminde kullanılmıştır. Irk Bitig'de sıfat olarak 'bay : er : koñl : ürküpen : barmış "Zengin bir adamın koyunu ürküp kaçmış." (Yıldırım 2017: 39) biçiminde tanıklanmıştır. Eski Uygur Türkçesi metinlerinde hem kişi adı parçası hem ikileme unsuru hem de sıfat olarak kullanılmıştır. Karahanlı Türkçesi metinlerinde de sıfat ve ikileme unsuru göreviyle yer almıştır. Yazıtlarda:

[...] çıgañ bodunug bay kıltım [...] "Yoksul halkı zengin ettim." (Aydın 2017: 50, 60, 88, 76) [KT G10, KT D29, BK D23, BK K7]

[...] çıgañıg bay kıltı azıg üküş kıltı [...] "Yoksulu zengin etti, az (halkı) çoğalttı." (Aydın 2017: 84) [BK D14]

ifadeleri yer alır. Devlet yöneticisinin önemli görevlerinden bir tanesi, yoksulluğu gidererek halkın refah seviyesini yükseltmektir. Bunu başarmış olmanın gururu, yazıtlara böyle yansımıştır. Burada da yine aralıklı bir ikileme yapısı söz konusudur. Yoksul olmanın karşit durumu zengin olmaktır. İkilemenin ses benzerliği sinırlıdır ve / ̃̃/ (ny) sesinin telaffuzunda hissedilen /y/ sesiyle kurulmuştur. Her iki sözcüğün sonunda da söyleyişte y sesi duyulmaktadır. Böylece zayıf da olsa bir ses benzerliğinden söz edilebilir. Yoksul sözü ile zengin ifadesi arasında, doğal bir karşıtlık ilgisi bulunması ve aralarındaki ses benzerliği bu yapının ikileme olarak kabul edilmesi için yeterli görünmektedir. Hem unsurları arasındaki anlam ilişkisi hem de ikilemenin genel anlamı itibariyle çıgañ bay ikilemesi karşıt anlamlı ikilemeler kapsamındadır. Söz konusu ikileme, eski Uygur evresi metinlerinde tanıklanmazken Kutadgu Bilig'de: 


\section{J(G)}

[...] çı̇ay bay ikigün ölümde kiḍin [...] (Arat 1979: 363 / 361)

biçiminde tanıklanmıştır. Burada da anlam ve fonksiyon yazıtlardakiyle aynıdır.

\section{6. ilgerü kurıgaru / kün tugsuk kün batsık}

İlgerü sözcüğü, Kırgızistan yazıtlarından Koçkor-4 (Kök Say 4) yazıtının ilk satırında:

munda ilg(e)rü (eb?) koş "Buradan ileriye (doğuya) doğru ev(imiz)(?) bark(ımız)(?) [bulun-

maktadır]." (Alimov 2014: 168)

Tes yazıtının güney 3. satırında:

[...] <...> élser ilgerü kontı [...] “Elser? doğuya yerlești.” (Aydın 2018: 37)

Şine Usu yazıtının doğu 8. satırında:

[...] ol yıl küzün ilgerü yorıdım [...] “O yıl güzün doğuya doğru yürüdüm.” (Aydın 2018: 57)

I. Karabalgasun yazıtı III/8'de:

[...] <...> ilgerü kün tugsuk <...> [...] “doğuda gün doğumu” (Aydın 2018: 68)

Tariat (Terh) yazıtının batı 5. satırında:

[...] <i>ligerü uçı [...] “doğu ucu” (Aydın 2018: 45)

biçiminde kullanılmıştır. Sözcük, büyük kağanlık yazıtlarında da sıkça geçmektedir. Kurıgaru sözcüğü ise yalnızca büyük kağanlık yazıtlarında tanıklanmıştır. Kurıgaru sözcüğü kurı adına getirilen \{+gArU\} yön gösterme ekiyle kurulmuştur. Bu ek, eklendiği sözcüğe hem yönelme hem de bulunma durumu fonksiyonu kazandırmaktadır. Sözcük için 'batıya, batıda' karşıllı̆ı verilmektedir. İlgerü sözcügünde ise durum biraz daha farklıdır. Sözcük \{+gArU\} ekini almakla birlikte, yalnızca 'doğuya, doğuda' anlamını değil aynı zamanda Alimov'un da işaret ettiği üzere, 'ilerideki bir yeri' de işaret etmektedir. Karahanlı Türkçesi dil özelliklerinin görüldüğü Kur'an Tercümesi'nde ilgerü sözcüğü, ‘ön, önce’ anlamına gelmek- 


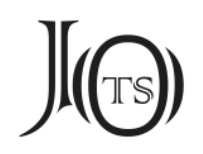

tedir. Ayrıca, ilgerü ıd- 'önceden yapmak', ilgerü kel- 'ilk, önceden, yapmak, sunmak' ve ilgerü keç- 'öne geçmek' biçiminde kullanımları da bulunmaktadır. Bu veriler gösteriyor ki \{+gArU\} eki ilk sözcüğüne eklenmiş, daha sonraki süreçte ise yazıtlarda görülen formunu almıştır. O dönem Türk toplumunun 'başı, önderi, ilk akla geleni' olan kağanın doğuda oturması başta olmak üzere, pek çok gösterge doğunun daha kıymetli görüldüğünü göstermektedir. 'Birinci olma, önde bulunma, ileride yer alma' anlamlarının 'doğu' ile bağdaştırıldığı anlaşılmaktadır.' Öyre sözcüğü de benzer bir anlayışla hem ön hem de doğu sözcüklerini karşılamakta kullanılmıştır. Sözü edilen iki sözcük, büyük kağanlık yazıtlarında arka arkaya:

[...] kayım kagan süsi böri teg ermiş yagısı koñ teg ermiş ilgerü kurıgaru sülep té[r]miş (?) kuwratmış kamagı yéti yüz er bolmış [...] "Babam kağanın ordusu kurt gibiymiş, düşnmanı koyun gibiymiş. Doğuya (ve) batıya sefer edip (adam) derleyip, toplamış. Tamamı yedi yüz asker olmuş." (Aydın 2017: 55, 82) [KT D12, BK D11]

biçiminde kullanılmıştır. Burada yer alan ilgerü kurıgaru ifadesiyle anlatılmak istenen gerçek anlamda doğuya ve batıya doğru gidildiği değildir. İşe yarayacak adamların, 'oradan buradan; sağdan soldan; ileriden geriden; arana tarana' bulunarak bir araya getirilmesi olayı, ahenkli bir deyişle ikileme formu içerisinde dile getirilmiştir. Elteriş Kağan'ın daha fazla beklemeyip, isyan ederek etrafına yiğit savaşçıları toplamak suretiyle, kağanlığı eski güzel günlerine döndürme çabaları, yazıtların bu kısmında mecazî anlatımla, benzetmeler ve ikileme kullanımlarıyla etkileyici bir tarzda anlatılmaktadır. Bu ifade biçimleri, anlatılan sıradan olayların dahi gelişigüzel değil seçilmiş, etkileyici sözlerle aktarıldı̆̆ını göstermesi açısından dikkat çekicidir. İlgerü kurıgarı ifadesi bu yönüyle, bilinçli olarak kullanılmış bir ikileme yapısıdır. Sözcükler arasındaki ses benzerliği, iki sözcüğe de getirilen \{+gArU\} ekiyle sağlanmıştır. İkilemenin taşıdığı geniş anlam, unsurları arasında kurulu bulunan karşıtlık ilgisini bozmamaktadır. Bu itibarla, ilgerü kurıgaru ikilemesi zıt anlam taşıyan bir yapıdadır.

İlgerü kurıgaru ikilemesine benzer bir kullanım Suci yazıtının 4. satırında geçmektedir:

6 ilkgerü için ayrica bk. ED 144a. 


\section{$J(\Theta)$}

[...] küm sorugum kün tugsuka <kün> batsıka tegdi [...] "şanım şöhretim gün doğusundan (gün)

batısına (kadar) [doğdan batıya] ulaştı.” (Aydın 2018: 86-87)

Burada da ifade edilmek istenen, Boyla Kutlug Yargan adlı Kırgız komutanının adının, sanının gerçekten de doğu ve batı yönünde yayıldığı değildir. Anlatılmak istenen, adı geçen komutanın şanının, sınırlar aştığı ve pek çok memlekete yayılmış olduğudur. Bu ifade de yine arasında karşıtlık ilgisi bulunan sözcüklerin kullanımıyla etkileyicilik kazanmıştır. Bu yapıya benzer bir kullanım Karahanlı Türkçesiyle yazılmış Kur'an tercümesinin İstanbul nüshasında da geçmektedir:

[...] tanrıķa turur kün tug̉usığ kün batsıg k̦ança kim [...] (Kök 2004: 13)

[...] aygıl tanrıḳa kün tug̉usıg் kün batısıg் [...] (Kök 2004: 15)

[...] aydı kün tog̉usug iḍisi kün batsığ iḍisi [...] (Ünlü 2004: 80)

\section{7. kün tün / tün küntüz / tünle küntüz / tün kün / tünli künli / yarın kéçe}

Evrende bazı kavramlar zıddıyla bilinmektedir. Anlamsal karşılıkları verilirken dahi birbirine ihtiyaç duyulan bu ifadelerden en sık kullanılanları arasında 'gece ve gündüz' sözcükleri ayrı bir yer tutar. Gündüz; gece var olduğu için kıymetlidir. Gece de gündüz sayesinde değer kazanır. Türk dili, tarihi lehçelerden günümüze değin bu karşıtllğı, ahenk unsuru olarak da kullanmıştır. Eski Türk yazısıyla yazılmış yazıt ve el yazmalarında gündüz ve gece kavramları birden fazla sözcükle karşılanmıştır. Bu sözcükler farklı formlar içerisinde, farklı ikilemelerin unsuru olarak kullanılmış ve metinlere ahenk ve etkileyicilik katmıştır. Benzer anlam ve fonksiyonları karşılamaları nedeniyle, çalışmanın bu aşamasında, yukarıda ifade edilen yapılar birlikte değerlendirilecektir:

Kün sözcüğü, eski Türk yazıtlarında hem güneș hem de gün kavramını karşılamak için kullanılmıştır. Güneş çıktığında gün de başlamaktadır. Kün sözcüğü, güneşin gün içerisinde gökyüzünde görüldüğg̈ zaman dilimini içermekle birlikte. kün batsık, kün tugsık gibi ifadelerde yer-yön bildirmiştir. Ayrıca KT G-D'deki yigirmi kün kullanımında, kün sözcüğü bir günün tamamını işaret etmektedir. ŞU G7'deki on kün ve Mainz 386 A 4-5'deki üçünç küninte ifadeleri de aynı kullanımı 


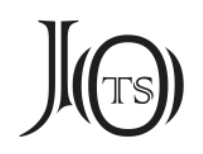

göstermektedir. Yenisey bölgesi yazıtlarında, kün sözcüğü genellikle ay sözüyle birlikte kullanılmış ve 'güneş' kavramını karşılamıştır. Sözcük, Yenisey yazıtlarında ayrıca kişi adı parçası olarak da kullanılmıştır. Dağlık Altay Cumhuriyeti yazıtlarından olan Kuray II yazıtında ot ç(a)k! kün(ü)m kop <...> // ut(d)(a)ç(l) kün(ü)m kop 'Ateş çak (yak)? Zafere ulaştı̆̆ım günler çoktur? / Zafer dolu günlerim artıyor?' ifadesi yer almaktadır (Tibıkova vd. 2012: 119-120). Burada da kün sözcügü hem bir günün tamamını işaret etmiş hem de daha geniş bir anlatımla 'geçen zamanı' anlatmakta kullanılmıştır. Eski Uygur Türkçesi metinlerinde kün sözcüğ̈̈, yazıt ve el yazmalarında kullanıldığ 'güneş, gün ve geçen zaman' anlamlarını devam ettirmekle beraber, yine güneşle ilintili olarak 'güney' yönünü karşılamakta da kullanılmıştır. Kün sözcüğü, Karahanlı Türkçesi metinlerinde, sözü edilen bu anlamlarıyla kullanılmaya devam etmiş, ayrıca él kün ikilemesinin bir unsuru olarak, 'millet, halk, memleket' kavramını da karşılamıştır.

Tün sözcüğü yazıtlarda 'gece' kavramını karşılamanın yanında tün orto ifadesiyle yön bildirmek için de kullanılmıştır. Bu kullanım Irk Bitig 24’te:

[...] teglük : kulun : érkek : yuntta : emig : tileyür : kün : orto : yütürüp : tün : orto : kanta : negüde : bulgay $: o l[. .$.$] "Kör bir tay, erkek atta meme istiyor. Gün ortasında kaybedip gece yarısı$ nerede, nasıl bulacak?” (Ylldırım 2017: 38)

biçiminde 'zaman' ifade etmekte de kullanılmıştır. Eski Uygur Türkçesi metinlerinde 'gece' kavramının yanında 'karanlık' sözünü karşılamakta da tün sözcüğü kullanılmıştır. Sözcük, Karahanlı Türkçesi metinlerinde 'geceyi’ işaret etmekle birlikte, günümüz Türk lehçelerindeki anlamıyla 'önceki gün’ü ifade etmek için de kullanılmaya başlamıştır. Belki de tün sözcügünün böylesi bir 'önceki gün' ifadesini karşılamasındaki mantık, geceyi bitiren güneşin doğmasıyla o gecenin artık önceki güne ait olduğu düşüncesidir. Bu itibarla yeni gün, güneşin doğuşuyla başlamaktadır. Bu noktada da eski Türkçede kün sözcüğü hem güneşi hem de güneşin doğumuyla başlayan yeni günü işaret etmektedir. Günümüzde kullanılan modern zaman dilimi nitelemelerinde ise önceki gün 24 saatlik dilimin tam yarısı olan 23.59'da bitmekte 00.00'da yeni gün başlamaktadır.

Kün ve tün sözcükleri, bu bölüme başlarken ifade edilen bazı kavramların karşıtıyla var olma meselesinin güzel bir örneğini oluşturmaktadır. Sözcükler arasında, daha oluşum aşamasından süregelen bir ses benzerliği ile anlam ilişkisi 


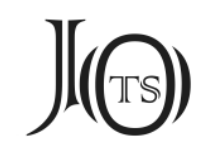

bulunmaktadır. Bu nedenle, söz konusu iki sözcüğün farklı formlarıyla çeşitli ikilemeler teşekkül etmiştir. Bu ikilemelerden biri olan kün tün, Tonyukuk 1 yazıt1nın kuzey 3. satırında görülmektedir:

[...] kün yeme tün yeme yelü bardımız [...] “Gece gündüz demeden hızla ilerleyip ulaştık.” (Ay$\operatorname{din} 2017: 111)$

Bu ikileme hem eski Uygur hem de Karahanlı Türkçesi metinlerinde de kullanılmıştır. Bu kullanımlara birer örnek aşağıda verilmiştir:

[...] küni tüni kitmişärsär [...] (Zieme 1985: 4)

[...] kün yimedi kör tünün yatmadı [...] (Arat 1979: 21/38)

Kün tün ikilemesinin unsurlarının yer değiştirmesi sonucu oluşmuş tün kün ikilemesi ise Tonyukuk 1 yazıtının doğu 5. satıında ve Or. 8212 / 78 (Ch. 0014) numaralı el yazmasının B Fragmanının A (B?) Yüzünün 3.- 4. satırlarında geçmektedir:

[...] ol sawın éşidip tün yeme udısıkım kelmez erti <kün yeme> olorsıkım kelmez erti [...] "O sözü işitip gece uyuyasım gelmedi, gündüz de oturasım gelmedi." (Aydın 2017: 109)

[...] tütünçs[üz: ot :yok: tüni : kü]ni :ök[ünç:yok [...] "Dumansız ateş yok, gece gündüz pişmanlık yok." (Ylldırım 2017: 282)

İkileme unsurlarının yer değiştirmesi olayı özellikle Eski Uygur Türkçesi metinlerinde sıkça görülen bir durumdur. Yazıt ve el yazmalarında ise bu durum nadiren görülür. Tün kün ikilemesi eski Uygur ve Karahanlı Türkçesi metinlerinde de sıkça kullanılmıştır. Bu ikilemenin geçtiği birkaç örnek aşağıda verilmiştir:

[...] tünüg künüg üzüksüz ärtürüp [...] (Wilkens 2007: 102)

[...] sini ķoldı tün kün bu emgek bile [...] (Arat 1979: 21/39)

T1 K3'deki ifade, 'ulaşılması gereken hedefe varıncaya kadar dur durak bilmeden, dinlenmeden' yapılan bir eylemi anlatmaktadır. Bu yapısıyla, tün ve kün sözcüklerinin karşıladıkları kavramlar, ikileme formu içerisinde daha geniş bir anlama gelecek şekilde kaynaşmıştır. Bu noktada, ikilemenin kazandığı anlamda 


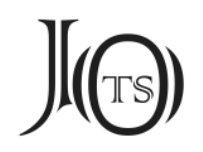

bir zıtlık görünmemektedir. Ancak, Tonyukuk burada yelü bardımız gibi daha basit bir ifadeye yer verebilirdi. Bunu yapmak yerine, Türk dilinin etkili ve ahenkli anlatımı mümkün kılan ikileme yapısını kullanmayı tercih etmiş olmalıdır. Böylelikle, hem anlatmak istediğine etkileyicilik kazandırma hem de sözünü güzelleştirme imkânını bulmuştur. Bu nitelikler tam da ikilemelerin önemli fonksiyonlarındandır. Tüni küni ökünçyok ifadesi de yine ‘süreklilik' bildirmektedir. Eski Uygur ve Karahanlı Türkçesi metinlerinde de bu kullanım mevcuttur. T1 D5'deki kullanımda, sıkıntıya sebep olan bir meselenin sürekli olarak Tonyukuk'un zihnini meşgul ederek onu rahat bırakmaması ifade edilmek istenmiştir. Burada 'süreklilik’ anlamı dolaylı olarak vardır. Bilge Kağan yazıtının güney doğu yüzünde:

\footnotetext{
kök ögüg yoguru sü yorıp tünli künli yéti ödüşke suwsuz keçtim [...] “Kök Öng (Ongi) 1rmağını (bata çıka) aşıp orduyu yürütüp geceli gündüzlü yedi gün boyunca susuz olarak geçtim. (Aydın 2017: 95-96)
}

ifadeleri yer almaktadır. Tünli künli ikilemesi de yine T1 K3'deki anlamı taşımaktadır. Burada da yine 'süreklilik' ifadesi yer almaktadır. Benzer bir kullanım Eski Uygur metinlerinden Daśakarmapathāvadānamālā'da da vardır:

\section{[...] tünli künli kurug ertürser [...] (Elmalı 2016: 206)}

Eski Türk yazısıyla yazılmış yazıt ve el yazmalarında bir de tün küntüz ikilemesi tespit edilmiştir. Kün sözcüğü yukarıda da ifade edildiği üzere daha geniş anlamlar içerirken küntüz sözcügü ise tek bir kavramı karşılamaktadır. Kün sözcüğünden türediği anlaşılan sözcük, yalnızca güneşin doğması ve batması arasındaki 'gün ışığının' hâkim olduğu zaman dilimini işaret etmektedir. Sözcüğün yapisında bulunan $\left\{+\right.$ tüz\} eki addan ad türeten bir ek gibi görünmektedir. ${ }^{7}$ Tün küntüz ikilemesi, yazıt ve el yazmaları içerisinde yalnızca büyük kağanlık yazıtlarında tanıklanmıştır:

\footnotetext{
Şirin 2019: 245'de küntüz sözcüğünün kün + tüz öğelerinden oluştuğu saptanmış, benzer yapılar olarak ise yultuz, kunduz, baltız örnekleri sıralanmıştır. Ayrıca, sözcükteki \{+tüz\} öğesinin bir sözcük mü yoksa ek mi olduğunun anlaşılmadığı belirtilmiştir.
} 


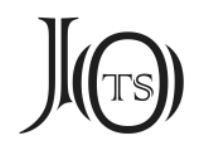

[...] atı küsi yok bolmazun] téyin türük bodun üçün tün udımadım küntüz olormad<ım> [...] "adı, sanı yok olmasın diye Türk halkı için gece uyumadım, gündüz oturmadım." (Aydın 2017: $59-60,88)$ [KT D27, BK D22]

[...] ol sawıg éşidip tün udısıkım kelmedi küntüz olorsıkım kelmedi [...] "O sözleri işitince gece uyuyasım gelmedi, gündüz oturasım gelmedi.” (Aydın 2017: 107) [T1 G5]

[...] <...>dı tün udımatı küntüz olormatı kızll kanım töküti kara terim yügürti işig küçüg bértim [...] "gece uyumadan gündüz oturmadan kızıl kanımı akıtarak kara terimi dökerek işi gücü verdim (hizmet ettim).” (Aydın 2017: 117) [T2 D1-2]

Köl Tegin ve Bilge Kağan yazıtlarının ortak satırlarından olan KT D27 ve BK D22'de, Bilge Kağan devleti için dur durak bilmeden, gecesini gündüzüne katarak nasıl çabaladığını anlatmaktadır. Bilge Kağan, geceleri düşünmekten gözlerini kırpmadığını, gündüzleri ise gece düşündüklerini tatbik etmek için dinlenmeden çalıştığını etkileyici ve estetik bir ikileme formuyla vurgulamıştır. T1 D5'te kullanılan tün kün ikilemesinde de görüldüğüü üzere, Tonyukuk da devleti için yaptığı hizmetleri anlatırken 'durmaksızın, sürekli olarak' çalıştığını bu iki ikileme formu içerisinde dile getirmiştir. Bu itibarla, tün küntüz ifadesi de 'süreklilik' bildirmektedir. Söz konusu ikileme, eski Uygur metinlerinde tanıklanmazken Karahanlı Türkçesi metinlerinde hem 'süreklilik' bildiren hem de doğrudan geceyi ve gündüzü işaret eden kullanımlarıyla tanıklanmıştır:

[...] ajun tüni kündüzi yelgin keçer [...] (Ercilasun-Akkoyunlu 2015: 470/1)

[...] yarattı ol uġan tünüg kündüzün [...] (Arat 2006: 41/13)

[...] tünün kündüzün bul açığlig k̦apuǵ [...] (Arat 1979: 377/3754)

[...] tün kündüz barmakıı kälmäki içindä [...] (Kök 2004: 17)

[...] uḍu barığl k̦lldı sizlerke tünni kündüzni [...] (Ata 2004: 50/12)

Yazıt ve el yazmalarında, gece ve gündüz karşıt sözcükleriyle kurulmuş ikilemelerden bir diğeri de tünle küntüz ikilemesidir. Bu ikileme U 181 (T II T) numaralı kâğıda yazılı metin parçasının B yüzünün 5. - 6. satırlarında geçmektedir:

[...] tegrim : küsi : küçi ulug kut tü[n]le küntüz yorısar [...] “Tanrım güç kuvvet, büyük (bir) talih versin. Gece gündüz yürüse" (Yıldırım 2017: 263) 


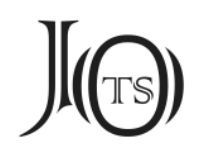

Her ne kadar, ikilemeden sonraki bölümün okunamaması nedeniyle satırın anlamı muğlak olsa da yapının yine 'süreklilik' ifade ettiği sezilmektedir. U 181 numaralı metin parçasının çoğu okunacak durumda değildir. Ancak anlaşıldığı kadarıyla, satırlar bir duanın parçasıdır. Metinde, verilen bir söz bir emir doğrultusunda, yerine getirilmesi gereken zor bir işe/yolculuğa istinaden dua edilmektedir. Duada inanılan 'güçten' güç kuvvet ve talih istenmektedir. Bu niyazlar ikileme formu içerisinde dile getirilmiştir. Sonrasında ise, işi / yolculuğu yapacak olanın, güç kuvvet ve talih bularak 'durmadan, sürekli, varıncaya kadar' yürümesini ve o işi/yolculuğu tamamlaması niyaz edilmiştir. Bu durum da yine ikileme formuyla aktarılmıştır. Yazıt ve el yazmalarında, tünle sözcüğünün tanıklandı̆̆1 tek yer burasıdır. Tünle sözcüğü yapısal açıdan tün + birle biçiminde açıklanabilir. Anlam açısından sözcüğün karşılığı da 'geceleyin' olarak ifade edilebilir. İkileme yapısında, ilk unsur anlam açısından kendinden sonraki unsurlara bağlanmaktadır. Tünle sözcüğünün yapısında yer alan birle ifadesi, sözcüğü yalnızca anlamsal olarak değil yapısal açıdan da küntüz sözcüğüyle ilintilemektedir. Birle ifadesinin, sözcüğün bu yapı içerisinde işaret ettiği 'gece' anlatımına herhangi bir etkisi yoktur. Günümüz Türk lehçe ve ağızlarında, söz konusu 'geceleyin' sözcüğü varlı̆̆ını sürdürmektedir. Tünle sözcüğü eski Uygur ve Karahanlı Türkçesi metinlerinde sıkça kullanılmıştır. İkilemenin, eski Uygur ve Karahanlı Türkçesi metinlerindeki kullanımlarına birer örnek aşağıda verilmiştir:

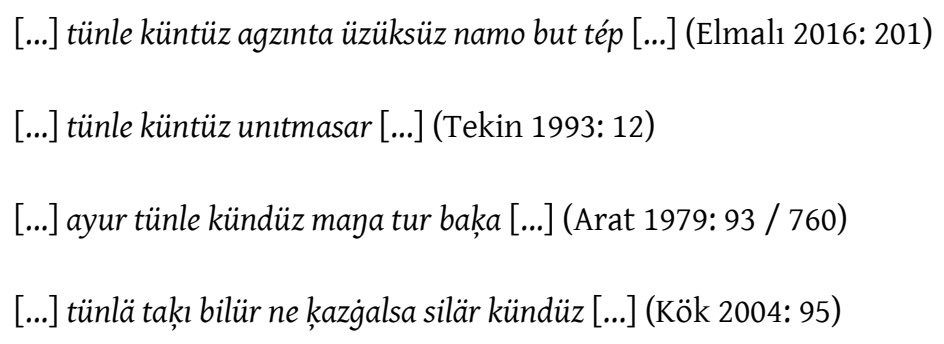

Yazıt ve el yazmalarında geçen gece ve gündüz karşıt kavramlarını barındıran son ikileme ise yarın kéçe ikilemesidir. Yarın sözcüğü yazıt ve el yazmalarında iki farklı anlamı karşılamak için kullanılmıştır. Bu anlamlardan ilki ‘sabah' kavramını işaret etmekteyken diğer anlamda ise 'kürek kemiği'ni ifade etmektedir. Yarın sözcüğü her iki anlamıyla da yalnızca Irk Bitig'de tanıklanmıştır. Bu durum, sözcüğün Uygurların bir diyalekt özelliğini yansıttığını düşündürmektedir. Sözcük, eski Uygur Türkçesi metinlerinde ‘sabah ve ertesi gün’; Karahanlı Türkçesi 


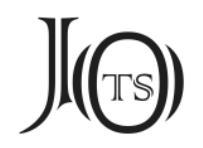

metinlerinde ise 'ertesi gün, omuz, sırt ve kürek kemiği' anlamlarıyla kullanılmıştır. Irk Bitig 40'da:

[...] talım : orı : yarınça : yasıçın : yalım : kayag : yara : urupan : yalyusun : yarıyor [...] "Yırtıcı kuzukapan, kürek kemiği kadar geniş ok temreniyle (=gagasıyla) yalçın kayaya yararcasına vurup yalnız başına yaşıyor." (Yıldırım 2017: 42)

ifadeleri yer almaktadır. Yazıt ve el yazmalarında kéçe sözcüğü ise Şine Usu yazıtının doğu birinci satırında tek başına; Irk Bitig 1, 2 ve 22'de ise yarın sözcüğüyle birlikte tanıklanmıștır. Bu tanıklamaların geçtiği yerler, yarın sözcüğünde olduğu gibi dikkat çekicidir. Eski Uygur ve Karahanlı Türkçesi metinlerinde de aynı biçimde kullanılan sözcük, 'gece' karşılığıyla günümüzde de kullanılmaktadır. ŞU D1' de:

[...] kéçe yaruk batar erkli sünüşdüm [...] ‘Gece, hava kararana kadar savaştım.” (Aydın 2018: 54)

ifadeleri bulunmaktadır. Burada kéçe sözcüğü, güneşin ufukta alçalmaya başlayarak alacakaranlığı oluşturduğu zaman dilimini işaret etmektedir. Satırın devamındaki 'tün térilmiş' ifadesinde geçen tün sözcüğü de artık güneş ışı̆̆ının hiçbir şekilde yeryüzünü aydınlatmadığı anları işaret etmektedir. Satırın sonlarında geçen 'kün tuguru' ifadesi ise güneş ışığının yeryüzünü ışıkla doldurduğu zaman dilimini anlatmaktadır. Satırdan anlaşıldığı üzere, çarpışma güneş batıncaya kadar yani kéçe'ye dek devam etmiş; karanlığın çökmesiyle yani tün'de düşman kuvvetleri yeniden toparlanmış; gün ışığıyla birlikte yani kün tuguru'da tekrar vuruşma olmuştur. Bu kullanımda, kéçe ve tün sözcükleri arasında bir anlam farkı olduğu anlaşılmaktadır. Kéçe olarak tanımlanan zaman diliminde henüz güneş ışı̆̆ı yeryüzünü belli belirsiz aydınlatmakta tün ve tünle sözcükleriyle ifade edilen zamanda ise zifiri karanlık yaşanmaktadır.

Yarın kéçe ifadesi ise Irk Bitig'de:

ten- :-si : men : yarin : kéçe : altun : örgin : üze : olurupan : menileyür : men [...] "Ben Tensi'yim! Sabah akşam altın taht üzerinde oturup mutlu bir şekilde yaşarım.” (Yıldırım 2017: 33)

ala:atlg: yol:tegri : men:yarın : kéçe:eşür:men [...] "(Ben, bir) alaca atlı yol tanrısıyım! Sabah akşam (atımla) rahvan giderim." (Yıldırım 2017: 33) 


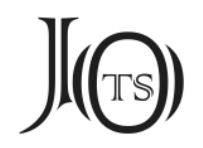

[...] uzuntonlug : közyüsin : kölke : ıçgınmış : yarın : yagrayur : kéçe : kegrenür [...] "Bir kadın, aynasını göle düşürmüş. Sabah akşam söyleniyor, sızlanıyor.” (Yıldırım 2017: 36)

biçiminde kullanılmıştır. Bu örneklerde görülen yapı, yukarıda yer verilen ikilemelerin karşıladığı 'süreklilik' ifadesini taşımaktadır. Kün tün, tün kün, tün küntüz, tünle küntüz, tünli künli ikilemelerinden farklı olarak yarın kéçe ifadesi, yapılan işin günün farklı bir zaman aralığı içerisindeki sürekliliğini anlatmaktadır. Yarın kéçe ikilemesi, ses benzerliğiyle değil anlam ilgisiyle kurulmuştur. İkileme, Uygur Türkçesi metinlerinde de kullanılmıştır:

\section{[...] yarın kiçä küyü kö[ädü] [...] (Le Coq 1911:4)}

Belki de tün sözcüğünün zaman içerisinde ‘önceki gün' ifadesini karşılamasındaki mantık, geceyi bitiren güneşin doğmasıyla o gecenin artık önceki güne ait olduğu düşüncesidir. Bu akıl yürütmede olduğu gibi, yarın sözcüğünün zaman içerisinde 'ertesi gün' ifadesini karşılamasındaki mantık da şu şekilde açılanabilir: Güneşin batmaya başladığı kéçe vaktinden sonra tün / tünle olarak ifade edilen zifiri karanlık yaşanmaktadır. Bu zifiri karanlıktan sonra, güneşin doğmasıyla başlayan 'sabah vakti' de yarın sözcüğüyle karşılanmıştır. Bu bilgiler ışığında, yazıt ve el yazmalarında geçen ifadelerden yola çıkılarak şu tespit yapılabilir: Güneşin doğmasıyla kün yani bir gün başlamaktadır. Güneş tepeye yaklaştığında kün orto, güneş batmaya başladığında kéçe, güneş tamamen batıp karanlık yeryüzünü kapladığında tün / tünle, gece yarılandığında tün orto yaşanmakta, güneşin doğmasıyla da yine yarın başlamaktadır.

Benzer anlamları karşılayan bu ikilemelerin, 'süreklilik' kullanımlarında her ne kadar bir karşıtlık sezilmiyor olsa da ikilemeyi oluşturan sözcüklerin doğrudan zıtlık ilgisi taşıması nedeniyle, bu yapılar da zıt anlamlı ikilemeler kapsamında değerlendirilmelidir. Zira bu ikilemelerin karşıladığı 'süreklilik' anlamı, Türk dilinin anlatımı güçlendiren, sözü güzelleştiren ve ifade zenginliği sağlayan yöntemlere başvurularak vurgulanmıştır. Yani bu yapılar, zıtlık ilgisi bulunan sözcükler kullanılarak kurulmuştur. Bu karşıt sözcükler yardımıyla ifade edilmek istenen duruma çarpıcıllı eklenmiştir. 


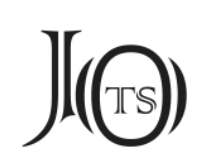

\section{8. ot suw}

Yazıt ve el yazmalarında ot sözcüğü 'ateş' ve 'bitki' anlamlarını karşılamak için kullanılmıştır. Sözcük, Köl Tegin ve Bilge Kağan yazıtlarında 'ateş' anlamılla ot suw ve otça borça ikilemelerinin bir unsuru olarak tanıklanmıştır. Dağlık Altay yazıtlarından Kuray II yazıtında 'ateş'; Kalbak-Taş XXIV yazıtında ise 'bitki' anlamiyla:

ot ç(a)k! kün(ü)m kop <...> // ut(d)(a)ç(l)kün(ü)m kop “Ateş çak (yak)? Zafere ulaştığım günler çoktur? / Zafer dolu günlerim artıyor?” (Tıbıkova vd. 2012: 119-120).

$s(\ddot{u}) c_{\zeta}(i) g$ ot : (a)z<...> "Tatlı ot(lar) : az? <...>" (Tibıkova vd. 2012: 92)

biçiminde tanıklanmıştır. Sözcük, eski Türk yazısıyla yazılmış el yazmalarında hem 'ateş' hem 'bitki' hem de 'ot sayun' biçiminde kişi adı parçası olarak da kullanılmıştır:

[...] tütünçs[üz: ot :yok: tüni : kü]ni : ök[ünç :yok [...] "Dumansız ateş yok, gece gündüz pişmanlık yok." (Yıldırım 2017: 282) [Or. 8212/78; (B) A 3]

[...] otka : könmiş : kll[1]ç : özike : yarlı : boltı [...] "Ateşte düzeltilmiş k1lıç Özi'ye verildi." (Yıldırım 2017: 271) [Or. 8212/76; (A) A 6]

[...] yaş : ot : körüpen [...] “Çayır çimen görerek” (Yıldırım 2017: 37) [IB, 17]

[...] kéyik: ogl : men : otsuz: suvsuz : kaltı : uyın : neçük:yorıyın tér [...] “(Ben bir) yabanî hayvan yavrusuyum! Otsuz (ve) susuz nasıl yapabilirim? Nasıl hayatta kalırım?” (Yıldırım 2017: 44) [IB, 45]

[...] yaş : ot : ündi [...] “Taze otlar çıktı.” (Yıldırım 2017: 46) [IB, 53]

Ot sözcüğü, eski Uygur ve Karahanlı Türkçesi metinlerinde 'ateş' ve 'bitki' karşıllklarının yanında 'ilaç' ve 'zehir' anlamlarıyla da kullanılmıştır. Suw sözcügü ise yazıt ve el yazmalarında 'su, nehir, ırmak, göl' anlamlarının yanında yér sözcüğüyle birlikte oluşturduğu ikilemede çok daha geniş bir anlam kazanarak 'vatan, toprak' karşllı̆̆ında kullanılmıştır. ${ }^{8}$ Çünkü 'vatan' kavramında, sahip olu-

8 Yér suw ifadesinin açılkanmasındaki farklı görüşler ve ayrıntılı bilgi için bk. Barutçu Özönder 1998; Seyidov 1996; Roux 2011: 56, 57, 90, 99, 102. 


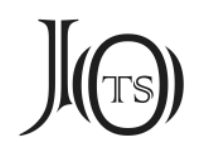

nan arazideki tüm kara ve su parçaları elinde bulunduran gücün tasarrufu altındadır. Bu yönüyle suw sözcüğünün üstlendiği anlam dikkat çekici bir boyuttadır. Hayatın kaynağı olarak Orta Asya bozkırlarında ulaşmanın oldukça güç olması nedeniyle de suw, önem atfedilen elementlerden biri olmuştur. Eski Uygur ve Karahanlı Türkçesi metinlerinde suw sözcügünün bu derin anlatımı daha da genişleyerek tüm yeryüzünü ifade etmek için kullanılır olmuştur. Ayrıca suw sözcüğü, eski Uygur metinlerinde astronomi literatürü içerisinde Mars gezegenini ve Su yıldızını karşılamak için de kullanılmıştır. Günümüz uzay araştırmaları sonucu 'su' bulunmayan bir gezegen olarak bilinen ve dünyanın milyonlarca yıl önceki halini andıran Mars gezegeninin neden suw sözcüğüyle ifade edildiği merak uyandıran bir meseledir.

Ot suw ikilemesi KT D27 ve BK D22'de tanıklanmıştır:

[...] ança kazganıp birki bodunug ot suw kılmadım [...] "Öylece elde edip birleşik halkları ateş

(ve) su gibi (birbirine) düşman etmedim.” (Aydın 2017: 60, 88)

II. Türk Kağanlığı, çeşitli Türk boylarından meydana gelmiş bir yapıdaydı. Bu boyların kendi beyleri vardı ve bu beyler kağana bağlıydı. Kağan, devletin bütününü ilgilendiren genel meselelerle ilgilenirken aynı zamanda boylar arasındaki münasebetleri de düzenlemekteydi. Boylar arasında çok kolay bir şekilde çatışmaların yaşanabildiği böylesi bir yapıyı idare etmek Türk kağanları için önemli bir yeterlilikti. KT D27 ve BK D22'de görülen ilgili satırlar işte bu yeterliliğin bir yansıması niteliğindedir. Bilge Kağan, kardeşi Köl Tegin ve iki şad ile birlikte dört bir yana dağılmış olan Türk boylarını öle yite bir araya getirdiğini, ikilemelerin ifade imkânları içerisinde hayretlere sunmaktadır. Bir araya getirilmiş olan boylar arasında sükûnetin sağlandığı, birbirine karşıtllı oluşturan ot ve suw sözcükleriyle anlatılmıştır. Suda ateş yanmaz ve su ateşin yanmasını sonlandıran bir yapıdadır. Bu anlam ilgisinin böylesi bir mecaz içerisinde dile getirilmiş olması, daha o dönemden Türk dilinin ne derece anlatım imkânlarına sahip olduğunu göstermektedir. Ot suw ikilemesi bu yönüyle hem unsurlarının bir araya geliş mantığı hem de kazandığı mecazî anlam açısından zıt anlamlı ikilemeler tasnifi içerisinde yer almalıdır. İkilemenin unsurları arasında ses benzerliği göze çarpmıyor olsa da söyleniş itibariyle birbirine yakın seslerin varlığı, ikilemeyi 


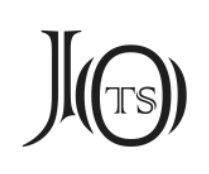

ahenkli bir niteliğe taşımaktadır. İkileme eski Uygur ve Karahanlı Türkçesi metinlerinde de kullanılmıştır:

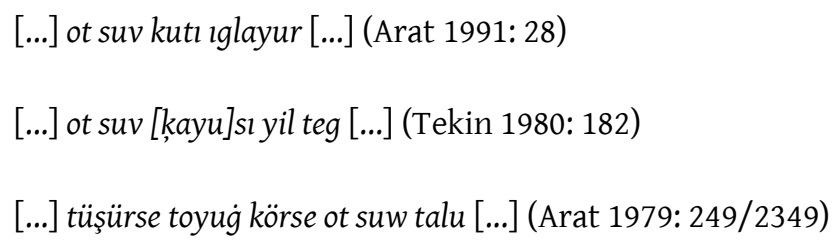

\section{9. tẹri yér / yér tẹri}

Tegri ve yér sözcükleri, eski Türk yazısıyla yazılmış yazıt ve el yazmalarında sıkça kullanımı bulanan sözcüklerdendir. Özellikle tegri sözcügünün anlamlandırılması ve üstlendiği fonksiyonların açılanması oldukça karmaşık bir mesele olup ayrı bir çalışmanın konusudur. Tegri sözcüğü 'gök, gökyüzü' anlamının yanında gerek kişi ve unvan adı parçası olarak gerekse de önem atfedilen kavramları açıklamakta kullanılmıştır. Yér sözcüğü ise 'yer, yeryüzü' anlamının yanında suw sözcügüüyle ‘vatan, toprak' karşıllğında da kullanılmıştır. Hem yer hem de gök kavramlarına, tarihin ilk zamanlarından itibaren çeşitli toplumlarca önem atfedilmiştir. Bu önem, kutsallık yüklenmesi veya derin bir saygı duyumu biçiminde kendisini göstermiştir. Çünkü yer ve gök, insanoğluna hem büyük imkânlar sunmuş hem de büyük felaketlere yol açmıştır. Türkler tarafından da kayıtsız kalınmayan bu durum, tarihi bilinen ilk yazılı metinlerden başlayarak günümüze değin kendini hissettirmektedir. Her iki sözcük de yalnızca birer coğrafi terim olarak kullanılmamıştır. Ancak yer ve gök kavramlarının, eski Türkçenin söz varlığından bağımsız olarak yalnızca mitolojik izahlarla açıklanmaya çalışılması bilimselliğe zarar vermektedir. Özellikle Orta Asya toplumlarının ortak mitolojik unsurlarının Türkler için de genellenmesi bazı sorunlara neden olmaktadır. Bu iki sözcügün açıklanması varsayımlara bırakılamayacak derecede hassastır. Bu aşamada, tegri ve yér sözcüklerinin ilişkili olarak kullanıldığı bağlamlar, karşıladıkları anlamların ayırt edilebilmesi adına teker teker aşağıda verilecektir:

[...] to[kuz ogu]z meniy bodunum erti tegri yér bulgakın üçün yagı boltı [...] "Dokuz Oğuz halkı kendi halkım idi. Gök (ve) yer karıştığı için düşman oldular." (Aydın 2017: 65) [KT K4] 


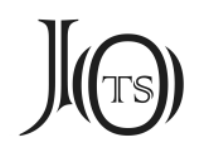

Burada, göğün ve yerin karışması ifadesiyle vurgulanmak istenen açık değildir. Yazıttaki satırlardan, o dönemde yaşanan karışıklıklar neticesinde ortamin toz duman olduğu anlaşılmaktadır. Bu ifadeyle, böylesi bir ortamda kimin ne yaptığının anlaşılamadığı vurgulanmış olmalıdır. Gök ve yer, yerli yerinde sağlam duran iki kavramı işaret etmektedir. Anlatılan dönemin, ne denli sıkıntılı olduğunun ifade edilebilmesi adına, bu iki kavramın dahi birbirine karıştığı vurgulanmıştır. Türk boyları arasında zaman zaman yaşanan çatışmalar bu satırlarda da ifade edilmiştir. Bilge Kağan kendi boyu olan Tokuz Oğuzların düşman olmasının nedenini, ancak böylesi imkân dâhilinde olamayacak bir duruma bağlamıştır. Burada birbirinin karşıtı durumunda olan yer ve gök sözcükleri, mecazî bir anlatıma bürünmüştür.

teĐrideki künke yérdeki élimke bökmedim "Gökteki güneşe (ve) yer(yüzün)deki yurduma doymadım.” (Aydın 2019: 60) [Barık III (E 7) 3]

Çeşitli toplumlarca gökyüzüne ve gökyüzündeki cisimlere değer atfedilmesi sıkça karşılaşılan bir durumdur. Burada, 'gökteki güneşe doymamak' ifadesi, iki biçimde açılanabilir. Bu söz ya güneşe duyulan derin bir saygının ürünüdür ya da dünyada görülecek günleri yani yaşamı işaret etmektedir. Bu yapıya hangi fonksiyonun yüklendiği ancak kapsamlı bir araştırmayla anlaşılabilir. Ölümü üzerine yazıtı dikilen kişinin bu dünyaya doymadan sevdiklerinden ayrılması olayı, arasında zıtlık ilgisi bulunan tegri yér formu içerisinde dile getirilmiştir.

[...] kulum küyüm bodunug tegri yér ayu bérti anta sançdım [...] "Kullarım, hizmetçilerim ve halkım (için) gök (ve) yer buyruk verdi, orada mızrakladım.” (Aydın 2018: 54-55) [ŞU D1-2]

Birbirine karşıtlık ilgisiyle bağlı bulunan tegri ve yér sözcükleri burada çok daha derin bir anlamı karşılamaktadır. Buradaki yapıda, yukarıda ifade edilen 'önem atfedilmesi' olayı görmezden gelinemeyecek bir tarzda belirgindir. Satırlarda anlatılan zorlu mücadelenin kazanılması, yerin ve gögün buyruk vermesiyle açıklanmıştır. Burada görüldüğü üzere, Türk kağanlarının, kazanılan başarıyı tek başına üzerlerine almayıp hem kolektif bir yapıya mâl etmeleri hem de daha büyük bir gücün yardımını vurgulamış olmaları dikkat çekicidir. Kazanılan 


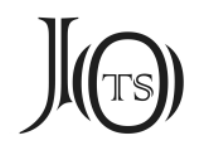

zaferlerin böylesi nedenlerle anlatılması, yazıtlarda başka noktalarda da bulunmaktadır. Bu durumun aynı ikileme formuyla görüldüğü bir diğer örnek ise ŞU G9'da geçmektedir:

[...] kü̈üm kulum bodunug tegri yér anta ayu [bé]rti anta sançdım [...] "Hizmetçilerim (ve) kullarım halkı(m) (için) gök (ve) yer öyle buyurduğu için (onları) orada mızrakladım.” (Aydın 2018: 61)

Tenri yér ikilemesi Irk Bitig 20'de de geçmektedir:

[...] ürüy : köpükümin: saçar:men: üze: tegrike:tegir:asra:yérke: kirür [...] "Beyaz köpüklerimi saçarım. (Köpüklerim) yukarıda gökyüzüne ulaşır, aşağıda yerin içine girer.” (Yıldırım 2017: 37)

Bir erkek devenin ağzından anlatılan bu satırlarda, saçılan beyaz köpükler abartılı bir ifadeyle aktarılmıştır. Etkileyiciliği ve söz güzelliğini abartılı bir söyleyişle harmanlayan bu satırlarda ahenk unsuru, karşıtlı ilgisiyle bağlı bulunan teyri yér sözcükleriyle sağlanmıștır.

İkilemelerin unsurlarının yer değiştirebildiğini gösteren örneklerden biri olan yér tegri yapısı, yazıt ve el yazmalarında üç yerde tanıklanmıştır:

[...] bilge ataçım yogun korugunun kazgantım <...> yér tegri öd<...>ç kirür er [ti] <...> "Bilge babac1ğım yoğ törenini (ve) anıt mezarını yaptırdım(?) <...> yer (ve) gök <...> girer idi.<...> (Aydın 2017: 126) [O K4]

$<\ldots>$ [yér] tegri kılıntokta uygur kagan olormış [...] "<...> yer (ve) gök yaratıllı̆̆ında Uygur Kağanı tahta oturmuş.” (Aydın 2018: 35) [Tes K1]

[...] yér ten[ri] pylsçbe(s?) [...] “<...> yer (ve) gök <...>” (Aydın 2019: 201) [Yır-Sayır II (E 94) 1]

$\mathrm{Bu}$ örneklerdeki kullanımların anlamsal derinliği, satırların okunamaması nedeniyle tam olarak anlaşılamamaktadır. Buna karşın, Tes K1'deki kullanımda açık bir biçimde yalnızca gök ve yer kavramlarına işaret edildiği anlaşılmaktadır. Tenri ve yér sözcüğünün unsur olarak kullanıldığı sözü edilen bu ikileme yap1sında ses benzerliği zayıftır. Her iki ikilemenin karşıtlık ilgisiyle sağlanan anlamsal bağı ise kuvvetlidir. Birbirlerine açık bir biçimde zıtlık ilgisiyle bağlı bulunan bu iki yapı, zıt anlamlı ikilemeler tasnifi içerisinde yer almalıdır. Eski Uygur Türkçesi metinlerinde de bu yapılar kullanılmıştır: 


\section{$J(\Theta)$}

[...] t(ä)yridäki yertäki [...] (Wilkens 2007: 80)

[...] yérke tegrike sevinç tutgll [...] (Arat 1991: 282)

[...] yér tegri törümisste [...] (Hamilton 1998: 13)

\subsection{0. ulug kiçig}

Ulug sözcüğü yazıt ve el yazmalarında, ‘ulu, büyük, yüce’ karşıllğının yanı sıra kişi ve unvan adı parçası olarak kullanılmıştır. Eski Türkçede sıfat göreviyle çok sık olarak kullanılmış olan sözcük, eski Uygur Türkçesi metinlerinde ayrıca ‘seçkin, asil' anlamıyla da tanıklanmıştır. Kiçig sözcüğü, 'büyük olanın' karşıt anlamlı sıfatı olarak yine yaygın bir biçimde kullanılmıştır. Sözcük, Irk Bitig 67'de yer alan kiçig déntar ifadesinde ise bir alçakgönüllülük anlatımı olarak 'ulu, yüce' anlamının karşıtı olarak tanıklanmıştır. Sözcük, eski Uygur ve Karahanlı Türkçesi metinlerinde 'genç' anlamıyla da kullanılmıştır. Zıtlık ilgisi taşıyan bu iki sözcük, ulug kiçig ikilemesinin birer unsuru olmuştur. Eski Uygur ve Karahanlı Türkçesi metinlerinde sıkça kullanılan bu ikileme, yazıt ve el yazmaları içerisinde yalnızca Yenisey bölgesi yazıtlarından Yeerbek I yazıtının 5. satırında:

[...] esizim e ulugum <a> kiçigim e bökmedim e yıta esizlerim e "Büyüğüme küçüğüme doymadım, eyvah! Ne yazı!!” (Aydın 2019: 233)

biçiminde tanıklanmıştır. Ulug ve kiçig sözcükleri arasında bulunan ses benzerliği, sözcüklere getirilen teklik birinci şahıs iyelik ekiyle kuvvetlenmiştir. Karşıtlık ilgisiyle bağlı bulunan iki sözcüğün unsur olarak kullanıldığı bu yapı, ikilemenin karşıladığı genel anlam açısından da açık bir şekilde zıt anlamlı ikilemeler tasnifinde yer almaktadır. İkilemenin eski Uygur ve Karahanlı Türkçesi metinlerindeki kullanımlarına birer örnek aşağıda verilmiştir:

[...] evinteki ulugı kiçigi barça bir ajunta [...] (Kaya 1994: 67)

[...] ulug kiçig ka kadaş ogul kız [...] (Bang vd. 1934: 346)

[...] uluǵka kiçigke silig ḳl sözüy [...] (Arat 2006: 69/356)

[...] uluġka kiçigke sewüg bol küle [...] (Arat 1979: 150/1327) 


\section{$J(\Theta)$}

\subsection{1. ürüy kara}

Ürüy sözcüğü, Bilge Kağan yazıtının kuzey 11.; Tonyukuk 2 yazıtının güney 4.; Kırgızistan yazıtlarından olan Talas-5'in 2. ve Irk Bitig'in 4, 5, 20 ve 41. satırlarında 'ak, beyaz' renk adı olarak sıfat göreviyle kullanılmıştır.

[...] sarıg altu]nın ürüy kümüşün [...] "sarı altını, beyaz gümüşü” (Aydın 2017: 78)

[...] sarıg altun ürüy kümüş [...] “sarı altın, beyaz gümüş” (Aydın 2017: 116)

[...] umaç ogh : it bert : ürü(ü)y küm(ü)ş)... s(a)gdıc... "Oğlu Umaç. Hediyeler, beyaz gümüşler... maiyet..." (Alimov 2014: 100)

[...] ürüy : esri : togan : kuş : men [...] “(Ben, bir) ak benekli doğanım!” (Yıldırım 2017: 34)

[...] ürüy : ingeni : botolamış [...] "Beyaz devesi yavrulamış.” (Yıldırım 2017: 34)

[...] ürüg : köpükümin : saçar : men [...] “Beyaz köpüklerimi saçarım.” (Yıldırım 2017: 37)

ürüy : esri : ingek buzagulaçı : bolmış : ölgey : men : témiş : ürüy : esri : érkek : buzagu : kelürmiş [...] "Ak benekli bir inek buzağılamak üzereymiş. (İnek) öleceğim diye düşünmüş. Ak benekli bir erkek buzağı dünyaya getirmiş." (Yıldırım 2017: 42)

Sözcük, Dağlık Altay Cumhuriyeti yazıtlarından Kalbak-Taş XXIII'de kişi adı olarak kullanılmıştır:

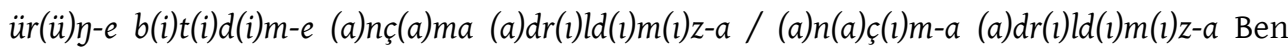
Ürün('üm). (Bunu) ben hâkkettim. Öylece ayrıldık! / Annemizden ayrıldık!” (Tibıkova vd. 2012: 90-91)

Sözcük, Yenisey bölgesi yazıtlarından E 11 numaralı Begre yazıtının 3. ve E 45 numaralı Köjeelig-Hovu yazıtının 7. satırında ‘soylu' anlamında kullanılmıştır. Bu kullanımda sözcük, 'soylu' ifadesinin karşıtı olan 'avam' kavramıla birlikte ürüy kara ikilemesinin bir unsurunu oluşturmuştur.

[...] ürünümüg e karamıg a azdım a "Soylu (ve) avam (halkımdan) ayrıldım (öldüm).” (Aydın 2019: 70)

[...] ürüyüm karam esiz yüz elig erim e esizim e "Soylu (halkım), avam (halkım), ne yazık! Yüz elli askerim, ne yazık!” (Aydın 2019: 151-152) 


\section{J(৫)}

Sözcük ayrıca, Şine Usu yazıtının doğu 10. satırında geçen ürüg beg biçiminde bir ifadede de tanıklanmıştır. ${ }^{9}$

Kara sözcüğü, yazıt ve el yazmalarında sıkça geçen sözcüklerdendir. Sözcük, renk adı olan 'siyah' anlamında, kişi ve yer adı parçası biçiminde ve 'soylu' kavramının karşıt anlamlısı olarak 'avam, sıradan' karşılığında kullanılmıştır.

Tarihin ilk çağlarından itibaren renk adları, isimleri renk yönünden nitelemenin yanında simgesel olarak da kullanılmıştır. Bu simgesel anlatımlar 'ak' ve 'kara' sözcüklerinde de kendisini hissettirmiştir. Beyaz rengi yüksek zümrenin seçkinliğini vurgulamış, kara sözcüğü ise bunun tam zıttı olarak sıradanlığı temsil etmiştir. Simgesel boyutta kullanılan ürü̈ kara ikilemesinin, unsurları arasındaki bağ, ses uyumu yönünden değil zıtlık ilgisiyle kurulmuştur. Bu itibarla, söz konusu ikileme zıt anlamlı ikilemeler tasnifi içerisinde değerlendirilmelidir. İkileme, eski Uygur Türkçesi metinlerinde de tanıklanmıştır. Aşağıda örnekte satırların tam olarak okunamaması nedeniyle, ikilemenin hangi anlamda kullanıldığı anlaşılamamaktadır. Bununla birlikte ürüy sözcüğü eski Uygur ve Karahanlı Türkçesi metinlerinde daha çok renk bildirmek için kullanılmıştır:

\section{[...] yaş[ay]u yürüg kar[a] bilmädin [...] (Zieme 1985: 94)}

\subsection{2. yalan tonlug}

Yalay sözcüğ̈̈, Yenisey yazıtlarından E 9 numaralı Kara-Sug yazıtının 3. satırında:

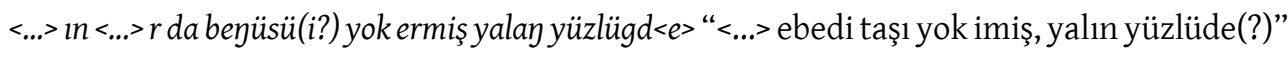
(Aydin 2019: 63)

biçiminde geçmektedir. Satırın tam olarak okunamaması nedeniyle ifade edilen anlamı kestirmek mümkün değildir. ${ }^{10}$ Sözcük büyük kağanlık yazıtlarında ise iki farklı ikilemenin unsuru olarak kullanılmıştır. Bu ikilemelerden ilki yakın anlamlı bir yapı olan yadag yalay ifadesidir:

ürüy beg ifadesi için bk. Aydın 2018: 191-192.

10 İlgili satır için ayrıca bk. Aydın 2019: 64. 


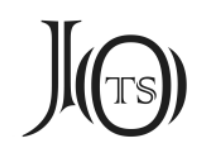

[...] yér sayu] barmış bodun ölü yitü yadagın yalanın yana kelti [...] "her yana dağılmış halk ölmek üzere (idi).Yaya (ve) yalın (bir hâlde) dönüp geldiler.” (Aydın 2017: 60) [KT D27-D28]

[...] yér sayu barmış bodun [yadagın yalaıın] ölü yitü <...> kelti "her yana dağılmış halk yaya (ve) yalın bir hâlde, öle yite <...> geldiler" (Aydın 2017: 88) [BK D22-D23]

Satırlarda, Bilge Kağan tahta geçtiğinde, dört bir yana dağılmış olan perişan halkın, büyük yokluk ve sıkıntılar içerisinde eski yurtlarına geri dönmeye başladıkları anlatılmaktadır. Bu yapı Kutadgu Bilig'de de geçmektedir:

[...] isig tumlig aç tok yadaġ hem yalı [...] (Arat 1979: 306/2961)

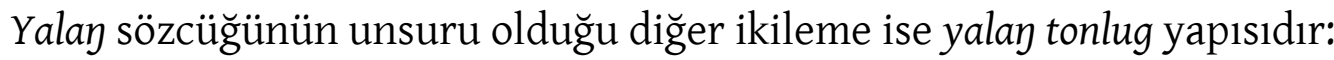

[...] yalay bodunug tonlug <kıltım> [...] "Sırtı açıkta olan halkı giydirdim." (Aydın 2017: 60, 88) [KT D29-BK D23]

Ton 'elbise, giysi' sözcüğü yazıt ve el yazmaları içerisinde, KT D29 ve BK D23'de \{+lIg\} addan ad türeten eki almış tonlug biçimiyle, KT D26 ve BK D21'de ise yine addan ad türeten \{+sIz\} ekini almış tonsuz biçimiyle geçmektedir:

[...] içre aşsız taşra tonsuz yawız yawlak bodunta üze olortum [...] "Karnı aç, sırtı açıkta olan, kötü durumda (ve) perişan bir halka kağan oldum." (Aydın 2017: 59, 87-88) [KT D26-BK D21]

Bilindiği üzere \{+lIg\} eki eklendiği sözcüğün varlığına, \{+sIz\} eki ise yokluğuna işaret etmektedir. Bu anlamılla tonsuz sözcüğü, yala sözcüğüyle aynı anlama gelmektedir. Bu durum da yalay ve tonlug sözcükleri arasında bir karşıtlık ilgisi oluşturmaktadır. Yukarıda verilen tonsuz sözcüğünün geçtiği örneklerde, Bilge Kağan tahta çıktığı sıralarda Türk halkının ne denli sıkıntılar içerisinde olduğunu vurgulamaktadır. Burada kullanılan 'karnı aç, sırtı açık' ifadesi yüzyıllar süren bir kullanımla günümüze değin ulaşmıştır. Bilge Kağan, bu sıkıntılı günleri çalışarak aşmayı başarmış ve halkın refah seviyesini yükseltmiştir. Kendi icraatlerini de kalıplaşmış ve biraz da mecazî anlatımlarla destekleyerek anlatmıştır. Az halkın üküş; çıgañ halkın bay; yalą halkın tonlug kılınması benzer ifade biçimlerini göstermektedir. Bu ifadeler yalnızca gerçek anlamlarıyla; az olan nüfusun çoğaltılması, fakirin zengin hâle getirilmesi veya gerçekten üzerinde giyecek elbisesi olmayana elbise bulunması durumunu anlatmamaktadır. Burada aynı za- 


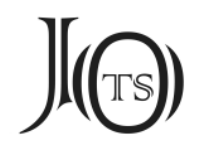

manda mecazî bir anlatım söz konusudur. Asıl ifade edilmek istenen, halkın durumunun iyileştirilmiş; devletin güçlendirilmiş olmasıdır. Başa geçmeden önce halkın ne durumda olduğu ile hükmeder olduktan sonraki tablonun karşılaştırılması günümüz siyasetinde de sıkça görülen bir durumdur. Günümüzde de yaygın olarak kullanılmaya devam eden bu kalıplaşmış ifadeler, barındırdıkları karşıtlık ilgisiyle söze dikkat çekicilik katmaktadır. Yalay tonlug ikilemesi, unsurlarından birinin ek almayıp diğerinin ise yapım eki aldığı; unsurları arasında ses uyumundan ziyade anlam ilgisi bulunan bir ikileme yapısıdır. Hem unsurları arasında kurulu bulunan karşıtlık ilgisi hem de ikilemenin genel anlamı itibariyle yalan tonlug yapısı, zıt anlamlı ikilemeler kapsamında değerlendirilmelidir.

\section{Eylemlerden Oluşan Zit Anlamlı İkilemeler}

\section{1. at- tut-}

At sözcüğü sesteş kök niteliğinde bir sözcüktür ve yazıt ve el yazmalarında genel olarak ad türündeki ‘binek hayvanı, at' ve ‘ad, isim' karşılıklarıyla kullanılmıştır. Eylem olan at- sözü ise Yenisey ile Dağlık Altay yazıtlarında tanıklanmıştır. Mendur-Sokkon 1 / 2 yazıtının ilk satırında, bu eyleme atıfta bulunan bir kullanımla kişi adı parçası olarak geçmektedir:

$\operatorname{er}(a) t(1)(a) t(a) r(a) p a[$ [..] “Erkeklik adı Atar Apa('dır).” (T1bıkova vd. 2012: 131-132)

Eylem, Kalbak-Taş IV / VI yazıtının ilk satırı ile E 41 numaralı Hemçik-Çırgakı yazıtının 7. satırında:

$y(a) g(1) z(e) r-a(1)$ dok (e)r(i)m at anı [...] "Yağız askerim, kutsal askerim, onu at! / onu vur!" (Tibikova vd. 2012: 73-74)

[...] awda géyik at<d>lm kan<l> ergey "Avlarda vurduğum yaban hayvanları! Hani nerede (şimdi onlar)?" (Aydın 2019: 135-136)

biçiminde geçmektedir. At- eylemi, o dönem av ve savaşlarda 'uzaktan atım / destek' silahı olarak kullanılan; ok, hançer, bıçak, balta veya mızrağın hedefe doğru fırlatıldığını ifade etmektedir. Bu silahlar arasında, Türklerin o dönemlerde en sık ve mahir olarak kullandıkları 'destek' silahı olan 'ok'un, buradaki ateylemini işaret ettiği söylenebilir. Nitekim Atar adı da yay kullanmakta mahir 


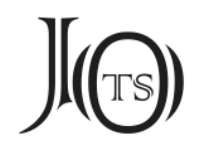

olan bir nişancıyı nitelemektedir. Savaşta okçulara verilen at! emri ile avda yabani hayvanların ok vasitasiyla 'vurulması' da yine bu at- eylemiyle ifade edilmiştir. Türk dilinde, günümüz modern 'ateş destek' vasıtalarıla yapılan atışlarda da yine at- eyleminin aynı fonksiyonu kullanılmaya devam etmektedir. Eylem bu anlamıyla, E 28 numaralı Altın-Köl I yazıtının 5. satırında, karşıtık ilgisiyle kurulmuş bir ikilemenin unsuru olmuştur:

atsar alp ertiniz e tutsar küç ertiniz e [...] "Atsanız, kahraman idiniz (ve) tutsanız güç(lü) idiniz." (Aydın 2019: 104)

Tut- eylemi, yazıt ve el yazmaları içerisinde birden fazla anlamı karşılamaktadır. Bu anlamlar: él tut- 'yurt tutmak, savunmak, toprak kazanmak, devlet yönetmek, ülkeye sahip çıkmak'; törö tut- 'yasa yapmak, düzenlemek, uygulamak'; at tut- 'benimsemek'; kü tut- 'ün kazanmak' olarak sayılabilir. Bu ifadeler daha çok mecazlı anlatımlardır. E 32 numaralı Uybat III yazıtının ilk satırında:

[...] kulı alp tutsar küç éçiçim e [...] "Kulu? Yiğitliği tutsa güçlü sevgili ağabeyim (için). (Aydın 2019: 118-119)

ifadeleri yer almaktadır. Burada kullanılan 'yiğitliği tutmak' sözü, kişinin 'sahip olduğu yeteneği, özelliği yansıtması, açığa çıkarması' biçiminde anlamlandırılabilecek bir ifadedir. Bu anlatım tarzı, 'yiğitlik, cesaret, şefkat damarının tutması' gibi farklı biçimlerde günümüzde de kullanılmaktadır. Bir de BK D10 ve KT D11'de töpösinte tut- 'tepelerinden (?) tutmak' ifadesi yer almaktadır. Tut- eyleminin karşıladığı yukarıdaki derin ifadelerden başka, doğrudan 'kavramak' anlamında kullanıldığı örnekler de vardır. Bu kullanıma ilişkin birkaç örnek aşağıda verilmiştir:

[...] tagdakı kara adıgıg eligin tut[dum] [...] "Dağdaki kara ayıların ellisini yakaladım." (Aydın 2019: 182-183) [El-Baj1 (E 68) 18]

[...] on totokyurçın yaraklıg eligin tutdı [...] "Ong Totok'un kaynını, silahlı (olduğu hâlde) eliyle yakaladı." (Aydın 2017: 61) [KT D32]

[...] türgéş kagan buyrukı az totokug eligin tutdı [...] “Türgeş kağanının komutanlarını (ve) Azların askeri valisini eliyle yakaladı." (Aydın 2017: 63) [KT D38]

[...] az éltewerig tutdı [...] “Azların elteverini yakaladı.” (Aydın 2017: 65) [KT K3] 


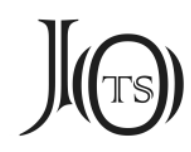

[...] kaganın tutdumuz [...] "kağanlarını yakaladık.” (Aydın 2017: 115) [T2 B6]

[...] eligçe er tutdumuz [...] “Elli kadar askerini yakaladık.” (Aydın 2017: 115) [T2 B7]

[...] elig tutdı [...] “ellisini ele geçirdi.” (Aydın 2017: 135) [KÇ B6]

Bu bilgiler ışı̆̆ında, Altın-Köl I yazıtının 5. satırındaki at- tut- ikilemesi, askerî bir niteliği ifade etmek için kullanılmıştır. Ölümü üzerine yazıtı dikilen kişi kendi ağzından, Bört ve Una Bars adlı iki kardeşini askerlik açısından övmüştür. Avda/savaşta, yay çekip ok 'attıklarında' büyük bir beceriyle kahramanlık gösterdikleri, yine avda/savaşta düşmanları veya yaban hayvanlarını 'yakalamakta, ele geçirmekte' yani 'tutmakta' ne denli güçlü oldukları anlatılmıştır. Ok atmakta ve adam yakalamaktaki beceriler, aralarında zıtlık ilgisi bulunan bu iki sözcük vasıtasıyla anlatılmıştır. Bu itibarla, ikilemenin unsurları arasında kurulmuş bulunan karşıtlık bağı ve ikilemenin genel anlamı açısından, bu ikileme de anlamsal tasniflerde zit anlamlı ikilemeler kapsamında değerlendirilmelidir.

\section{2. ér- bar-}

Er ve bar sözcükleri sesteş kök niteliği taşımaktadır. Hem ad hem de eylem olarak kullanılan bu iki sözcük, eski Türk yazıt ve el yazmalarında sıkça geçmektedir. Bar adı 'var, mevcut'; bar- eylemi ise 'varmak, gitmek, ulaşmak' karşıllğında tanıklanmıştır. Er adı 'erkek, koca, asker, adam ve kişi adı parçası'; er- eylemi ise 'olmak, imek' karşılığında kullanılmıştır. Aynı zamanda her iki eylem de yardımcı fiil görevi üstlenmiştir. Er- ve bar- sözcükleri, eski Türk yazıtlarında dört yerde birbiriyle ilişkili biçimde tanıklanmıştır:

[...] érmiş barmış edgü eline kentü yayıltıg yawlak kigürtüg [...] "her tarafa ulaşmış iyi (durumdaki) yurduna (karşı) sen kendin hata ettin (ve) nifak soktun." (Aydın 2017: 58) [KT D23]

[...] érmiş bar[mış edgü] eline kentü yayıltıg yawlak kigürtüg [...] "her tarafa ulaşmış iyi (durumdaki) yurduna (karşı) sen kendin hata ettin (ve) nifak soktun.” (Aydın 2017: 87) [BK D19]

[...] köl tégin yéti otuz yaşına karlok bodun erür barur erkli yagı boltı [...] "Köl Tegin yirmi yedi yaşında, Karluk halkı gelip gider iken (durduk yere?) düşman oldu." (Aydın 2017: 64) [KT K1] 


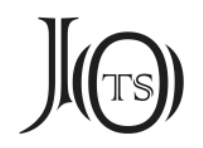

[...] otuz artukı bir yaşıma karlok bodun buysuz erür barur erkli yagı boltı [...] "Otuz bir yaşımda Karluk halkı sıkıntısızca hareket eder hâle geldi, (bundan dolayı) düşman oldu.” (Aydın 2017: 90-91) [BK D28-D29]

İlgili satırlarda yer alan ermiş barmış ve erür barur ifadeleri, bazı araştırmacılar tarafından bağlam içerisinde anlamlandırılmıştır. Kimi araştırmalar ise bu dört tanıklamanın da aynı biçimde anlamlandırılması gerektiği görüşündedir. Erbar- ikilemesi üzerine bir yazı kaleme alan UçAR’a göre, ikilemenin dört tanıklaması da aynı biçimde 'var olmak, hayatta olmak, yaşamak, mevcudiyetini sürdürmek' gibi anlamlara işaret etmektedir (2019: 495)

KT D23 ve BK D19 ortak satırlardır. Bu satırların öncesinde ve sonrasında yer verilen olaylar, benzer durumları vurgulamak amacıyla anlatılmıştır. Bilge Kağan KT D23'de yer alan satırların öncesinde, devletin eski güzel zamanlarına atıfta bulunmaktadır. Yönetimi ele alan her liderin yaptığı gibi yönetime gelmeden önce devletin ve milletin içinde bulunduğu sıkıntılı günleri anımsatarak kendi icraatlarını sıralamaktadır. Bunu yaparken de coğrafi yönlere, bölge ve boy isimlerine yer vermektedir. Böylesi bir anlatım biçimi er- ve bar-sözcüklerinin açılanmasında bir ipucu niteliğindedir. Zira devletin ulaştığı sınırlar bar- eyleminin 'gitmek, varmak, ulaşmak' karşılıklarını muhayyileye getirmektedir. Bilge Kağan yazıtın devamında ise, Türk halkının 'asi yaradılışlı' olması nedeniyle yok olmaya yüz tutmuş milleti derleyip toplayan kağanına karşı isyan ettiğini anlatmaktadır. KT D21-D22 ve BK D17-D18'de icraatlar sıralanırken kullanılan ét-, kazgan- kontur- eylemleri de yine bar- sözcüğünün 'gitmek, varmak, ulaşmak' anlamlarıyla ilişkilidir. Türk halkı asi yaratılışlı olduğu için, toprak kazanmış, ülke elde etmiş, yasalar tayin etmiş, halkı düzene sokarak dört bir yana yerleştirmiş olan Bilge Kağan'a isyan etmiştir. Bu itibarla, érmiş barmış edgü él ifadesi sınırları dört bir yana ulaşmış olan Türk ülkesine işaret ediyor görünmektedir. Er-sözcügünün burada karşıladığı anlam ise, bar- sözcüğünün 'varmak, ulaşmak, gitmek' anlamlarıyla ilişkili olmalıdır. Tonyukuk 2 yazıtının güney birinci satırında:

[...] temir kapıgka tegi értimiz [...] "Demir kapıya kadar ulaştık.” (Aydın 2017: 116) 


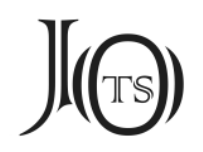

ifadeleri yer almaktadır. Buradaki értimiz eylemi $4 \mathbf{s} \mathbf{h} \Upsilon \Upsilon \uparrow$ biçiminde yazılmıştır. Açık bir biçimde buradaki sözcük er- 'imek, olmak' değil ér- 'erişmek, ulaşmak, varmak'tir. Aynı sözcük Uygur Kağanlığı yazıtlarında da aynı anlamda tanıklamıştır. ŞU D2-D3’te aynı anlam ve yazımda:

[...] udu kelin tédim kodup bardım kelmedi yiçe értim burguda yétdim [...] “Gelin (bana katılın) dedim. (Öylece) koyup bıraktım. Gelmedi(ler). Tekrar ulaştım. (Onlara) Burgu (Irmağı)'da yetiştim." (Aydın 2018: 55)

biçiminde geçmektedir. Sözcük yine, ŞU K8, G6 ve G8'de aynı anlamla $\aleph_{\mathrm{h}} \Upsilon \uparrow$ biçiminde yazılmıştır. Aynı sözcük, Hoyto-Tamır II yazıtının üçüncü satırında küzte toñın taşka értim 'güzün Tonyın Taş'a (Hoyto-Tamır?) ulaştım' (Aydın 2018: 74) ve Hoyto-Tamır VIII yazıtının dördüncü satırında késre toguzunç ayka értim 'sonra dokuzuncu ayda ulaştım' (Aydın 2018: 76) cümlesinde ise $\bigotimes_{\mathrm{h}} \mathrm{P}$ biçiminde aynı anlamda ama başındaki ünlü olmaksızın yazılmıştır. Sözcük ayrıca, Karabalgasun I, III/6'da érigme $\$ \gg \& \Upsilon$ biçiminde tanıklanmıştır. Örneklerden açık bir biçimde görüleceği üzere, eski Türk yazıtlarında tanıklanan ve 'ulaşmak, varmak' anlamını taşıyan ér- sözcüğünün yazımında iki farklı biçim söz konusudur. KT D23 ve BK D19'da geçen ér- eylemi, Uygur yazıtlarında görülen ve sözcügün başındaki ünlünün gösterilmediği biçimiyle yazılmış olmalıdır. Bu bilgiler ışı̆̆ında, ér- eyleminin anlamı netlik kazanmaktadır. Böylece farklı bir önermeyle, érmiş barmış edgü él ifadesi 'gidip gelmesi uzun sürecek derecede geniş topraklara ulaşmış, iyi durumdaki ülke' biçiminde anlamlandırılabilir. İkinci bir olasılıkta ise érmiş barmış edgü él ifadesi 'istenilen yere gelip gitmekte özgür olunan yani bağımsız olan, iyi durumdaki ülke' olarak da düşünülebilir. Her iki durumda da ikilemenin genel ifadesi aynı anlama işaret ediyor olsa da yapıyı oluşturan sözcükler birbirinin karşıtı durumundadır.

KT K1 ve BK D29' da geçen erür barur ifadesindeki ilk sözcük de yine 'erişmek, ulaşmak, varmak' anlamındaki ér- olmalıdır. Zira yapının ikinci unsurunun 'gitmek, varmak' karşılığındaki bar-sözcügü olduğu anlaşılmaktadır. İlgili satırlarda ikileme, Karlukların 'istediği yere gelip gitmekte serbest olan, rahat hareket eden’ bir durumda olduğunu anlatmaktadır. İkilemenin karşıladığı anlamı açıklamakta iki olasılık söz konusudur. İlk olasılıkta, Karluklar böylesi bir sıkıntısız 


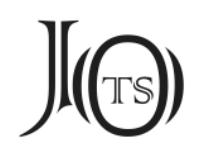

hareket alanına sahipken, mevcut durumda onların bu rahat hareket eder durumlarını kısıtlayacak herhangi bir gelişme yaşanmamışken düşman olmuştur. Karlukların bu durduk yere, herhangi bir neden olmaksızın düşman olmaları 'gelip gitme' konusundaki rahatlıklarına atfen érür barur ifadesiyle anlatılmıştır.

İkinci olasılıkta ise ikileme, Karluk boyunun başına buyruk hareket eder duruma geldiğini vurgulanmaktadır. II. Türk Kağanlığı, çeşitli boyların bir araya gelmesiyle oluşmuş bir yapıdaydı. Kimi dönemlerde, merkezi otorite zayıfladığında veya bir boy merkezi otoriteye güç yetirecek derecede güçlendiğini düşündüğünde, birlik içerisinde isyanlar yaşanmaktaydı. Bu durumda başkaldıran boy, kağanlığın buyruklarına uymayıp bağımsız hareket etmekteydi. KT K1 ve BK D29'da ifade edilen érür barur da bu kapsamda Karlukların 'merkezi otoriteye uymayıp istediği yere gidip gelmekte yani bağımsız hareket etmekte' olduğuna işaret etmektedir. Anlaşılacağı üzere her iki olasılıkta da sonuç aynıdır. Yalnızca Karlukların isyan nedeni farklılık arz etmektedir. İlk olasılıkta 'nedensiz' ikinci olasılıkta ise 'otoritenin zayıflaması/boyun güçlenmesi' nedeniyle oluşan bir başkaldırı söz konusudur.

Hareket etmenin doğasında istenilen yere 'gelip gitme' vardır. Bu açıdan érve bar- sözcükleri, zıt anlam maksadıyla kullanılmamakla birlikte birbirinin karşıtı durumundadır. Hem érmiş barmış hem de érür barur ifadesinde gerek ses gerekse de anlam ilişkisi söz konusudur. Sözcüklerin kökleri arasında ses benzerliğinin bulunması ve her iki unsurun da aynı eki almış olması nedeniyle ikilemenin ses uyumu kuvvetlidir. ${ }^{11}$

Eski Uygur Türkçesi metinlerinde bir de erig barıg 'hareket, davranış' ve eriglig barıglıg 'hareketli, davranışlı' ikilemeleri tanıklanmıştır. Burada erig barıg ifadesinin 'hareket' anlamına mı yoksa 'davranış' anlamına mı işaret ettiği açık değildir. İlginç olan nokta, kişinin içinde soyut durumda var olan bir anlayışın, performansa döküldüğünde yani bir 'hareket' sonucunda davranış olarak adlandırılabilmesidir. Eski Uygur Türkçesinde geçen bu iki ikilemenin tanıklamaları aşağıda verilmiştir:

${ }^{11}$ Er-ve ér- için ayrıca bk. ED 193b-194a. CLAUSON da érmiş barmış ve érür barur ifadelerindeki sözcüğün 'to reach, arrive' anlamındaki aynı ér- eylemi olduğu kanısındadır. 


\section{$J(\Theta)$}

[...] säviglig ımrak anıy yavlak äriglärin barıgların ürür [...] (Gabain-Kowalski 1959: 347)

[...] çoglug yalınlıg ärig[inizk]ä [barı]gıłızka [...] (Röhrborn 1991:178)

[...] biliglig edremlig tuzlug yaraglıg eriglig barıglıg bolurlar [...] (Kaya 1994: 116)

\section{3. kon- köç- / köçür- kontur-}

Ko- sözcüğüne, eylemden eylem türeten ve bu örnekte dönüşlülük anlamı katan \{-n-\} ekinin getirilmesiyle oluşan kon- sözcüğü, yazıt ve el yazmaları içerisinde Tes yazıtının güney 2. ve 3. satırlarında:

[...] [te]zig kasar kur<l>g kontı çıt tikdi örgin yaratdı yayladı [...] “Tes (Irmağı'nın) (kaynağına?),

Kasar'ın batısına yerleşti. Çit dikti, tahtını kurdurdu, yazı (orada) geçirdi.” (Aydın 2018: 37)

[...] élser ilgerü kontı [...] “Elser? Doğuya yerleşti.” (Aydın 2018: 37)

biçiminde tanıklanmıştır. Sözcük ilgili satırlarda 'yerleşmek, alana sahip olmak, alanı tutmak' anlamında kullanılmıştır. Burada kon- sözcüğü askerî bir uygulamaya işaret etmektedir. Ordu birlikleri çeşitli nedenlerle belli alanlara konuşlanmaktadır. Kon- sözcüğü, büyük kağanlık yazıtlarında ise daha çok 'yurt tutmak' anlamında kullanılmıştır. KT G5-BK K4'te yagru kontokda, KT G7-BK K5'te tögültün yazı konayın ve T1 G10'da ise ötüken yérig konmış biçiminde 'yaşamak amacıyla yerleşmek, yurt tutmak' anlamında kullanılmıştır. Sözcük, Irk Bitig 61 ve 64'de ise daha dar bir anlatımla, doğrudan 'konmak' karşılığında tanıklanmıştır:

turna : kuş : tüşnekine : konmış [...] "Bir turna, tüneğine konmuş." (Yıldırım 2017: 48)

kök : boymul : togan : kuş : men : körklüg : kayaka : konupan : közleyür : men [...] "(Ben, bir) ak boyunlu, boz doğanım! Geniş görüş alanına sahip kayaya konup (etrafi) gözetliyorum.” (Yıldirim 2017: 48)

Köç- sözcüğü ise eski Türk yazıt ve el yazmalarında yalnızca iki yerde tanıklanmıştır. Bu iki tanıklamada da kon- sözcüğüyle ilişkili olarak kullanılmıştır. Konköç- ikilemesinin bir unsuru olarak Tariat (Terh) yazıtının batı 4. satırında:

[...] tört bulundakı bodun <i>ş küç bérür yagım bölök yok bol[tı ötüken éli tegres él]i ékin ara ılagım tarıglagım sekiz seleye orkon tugla sewin teledü karaga bargu ol yérimin suwumun konur köçür ben "dört bucaktaki halklar hizmetimdedir. Düşmanım Bölök yok oldu. Ötüken yurdu ile Tegres yurdu, (bu) ikisinin arasındaki vadilerim (ve) tarlalarım sekiz 


\section{J(৫)}

(kollu) Selenge, Orhon, Tula, Sevin, Teledü, Karaga (ve) Burgu. Bu topraklarım (üzerinde)

(ve) ırmaklarım (boyunca) konup göçerim." (Aydın 2018: 45)

biçiminde geçmektedir. Kon- köç- ifadesi burada içinde bulunulan refahı ve rahatlığı anlatmaktadır. Düşmanlar itaat altına alınmış, ırmaklar ve topraklar zapt edilmiş, yaylak ve kışlaklarda istenildiği biçimde konup göçülmektedir. Burada kon- ve köç-sözcükleri, birbirinin zıddı kavramları ifade etmektedir. Bozkır yaşamında, hayvanların otlatılacağı, sert kışların daha yumuşak geçirilebileceği, düşman saldırılarına karşı daha rahat savunulabilecek ve su kaynaklarına yakın olan bölgelerin tespiti ve bu sahalarda etkinliğin kurulması hayati bir öneme sahiptir. Bu noktada, yaylak ve kışlaklara konup göçülmesi olağan bir durumdu. Hatta o dönemde, yazlık ve kışlık başkentler dahi vardı. İlgili satırlarda geçen yér suw ifadesi de bir ikilemedir ve su ile toprak parçalarına işaret ederek daha geniş bir anlatımla 'vatan' kavramını karşılamaktadır. Bu açıdan, konur köçür ben ifadesi, 'kendi vatanımda özgürce, istediğim yere halkımı yerleştirir; istediğim yerden göçürürüm/istediğim gibi yaşarım' anlamını içermektedir. Diğer bazı ikilemelerde görüldüğü üzere, burada da zitlık ilgisi bulunan sözcükler, daha derin anlamların ifadesi için ikileme formu içerisinde kullanılmıştır. Bu noktada, ikilemenin kazandığı genel anlam açısından değil unsurlar arasında doğal yollarla kurulu bulunan karşıtlık ilgisi nedeniyle kon- köç-ikilemesi zıt anlamlı ikilemeler tasnifi içerisinde yer almalıdır. İkilemeyi oluşturan sözcükler arasında hem sözcük köklerindeki benzer seslerin varlığı hem de aynı eklerin kullanımı açısından ses benzerliği de bulunmaktadır.

Kontur- sözcüğü, KT D2, BK D4'de konturmış; KT D21, D38, BK D17, D18'de konturtumuz; BK K11'de ise konturtum biçiminde 'yerleştirmek, yaşanacak yer kılmak' anlamında kullanılmıştır. Sözcük, E 100 numaralı Bayan-Kol yazıtının üçüncü satırında da geçmektedir. Anlam tam olarak açık olmasa da özin alıp kont<ur>madım (Aydın 2019: 206) biçiminde 'yurt tutmak, yaşanacak yer edinmek' anlamında kullanılmıştır. Kon- ve köç-sözcükleri, Irk Bitig 34’te birbiriyle ilişkili biçimde kullanılmıştır. Bu örnekte kon- ve köç- sözcükleri, aynı oldurganlık fonksiyonunu üstlenen \{-tUr-\} ve \{-(X)r-\} eklerini almıştır. Bu örnekte, köçür-sözcüğü ilk kontur-sözcügü ise ikinci unsur olarak kullanılmıştır: 


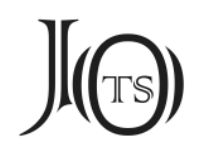

kan : süke : barmış : yagıg : sançmış : köçürü : konturu : kelir : özi : süsi : ögire : sevinü : ordosinaru : kelir [...] "Bir kağan savaşa gitmiş. Düşmanı bozguna uğratmış. (Düşmanlarını) göçürüp kondurarak geliyor. (Kağanın) kendisi askerleriyle birlikte kıvanıp sevinerek sarayına/karargâhına doğru geliyor." (Yıldırım 2017: 41)

Satırda ifade edilen köçür-ve kontur- eylemini yaptıran savaştan dönen kağandır. Ancak kağanın kimi göçürüp kondurduğu tam olarak belli değildir. Satırlar üzerinden yapılacak bir akıl yürütmeyle şunlar söylenebilir: Düşmanını yenerek başkentine/karargâhına doğru geldiğine göre kağan ve ordusu tek seferde dönülemeyecek derecede uzaktaki bir noktadadır. Bunun için kimi yerlerde kamp yapılması doğaldır. Bu noktada kağan, ordusunu uygun kamp alanlarına konuşlandırıp harekete geçirerek başkentine/karargâhına doğru ilerlemektedir. Söz konusu önerme doğrultusunda burada köçür-ve kontur-sözcükleri, derin bir anlatımı değil doğrudan temel anlamlarını içermektedir. Yerleştirmek ve harekete geçirmek anlamlarıyla bu iki sözcük arasında zıtlık ilişkisi söz konusudur. Zıt anlam ilgisinin yanında, sözcükler arasında hem kök seslerin benzerliği hem de sözcüklere gelen ekler açısından ses uyumu da kurulmuştur.

\section{Sonuç}

İkilemelerin doğru şekilde anlamlandırılması, eldeki sınırlı kaynak açısından bakıldığında eski Türk yazısıyla yazılmış yazıt el yazmalarının daha iyi anlaşılmasına büyük katkılar sunacaktır. İkilemeler, bir dilin söz varlığı içerisinde önemli fonksiyonlar üstlenen yapılardır ve bu yönüyle bağlamdan bağımsız olarak değerlendirilmeleri mümkün değildir. Hâlihazırda, ikileme konulu çalışmaların azlığı nedeniyle, konu hakkında açıklanması gereken pek çok mesele bulunmaktadır. İkileme teriminin doğru biçimde açıklanması bir yana, terimin nasıl adlandırılması gerektiği de sorunludur. İkileme yapıları üzerinde tartışmaya neden olan bir başka konu ise bu yapıların nasıl sınıflandırılması gerektiği üzerinedir. Yapılan bu çalışmada, eski Türk yazısıyla yazılmış yazıt ve el yazmalarında geçen, zıt anlamlı ikilemeler üzerinde durulmuştur. Zira yapılan sınıflamalar içerisinde, karanlık noktaların en çok bulunduğu bölüm budur. Çalışma sırasında bir kez daha görüldü ki ikilemeler üzerinde yapılacak tasnifler arasında asıl önem arz edenleri anlamsal olanlarıdır. Zira ikilemelerin yapısal tasnifinin önemi, hangi ikilemenin hangi yapıda olduğunun belirlenmesi değil ikilemelerin yapısal 


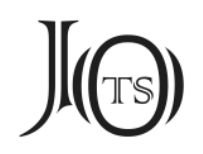

açıdan nasıl oluşmuş olduklarının incelenmesidir. Bu nedenden ötürü, yapılacak yapısal incelemelerin odak noktaları, sınırları dar ve açık bir biçimde belirlenmiş olmalıdır. Yani yapısal incelemeler makro değil mikro düzeyde olmalıdır.

İkilemeler, sıradan bir konunun dahi etkili, vurgulu ve ahenkli biçimde aktarılabilmesi imkânını vermektedir. Söz konusu çarpıcılık ve söz güzelliği kimi zaman eş kimi zaman yakın kimi zaman ise zıt anlamlar içeren sözcükler kullanılarak oluşturulmuş yapılarla sağlanmıştır. Bu noktada ikilemelerin tâbi tutulacağı anlamsal bir tasnifin üç alt sınıfı bulunmaktadır. Bunlardan ilk sınıflamada eş anlamlar içeren sözcüklerle oluşmuş yapılar bulunmaktadır. Bu yapıların tespiti ve anlamlandırılmasında bir güçlük yoktur. Nispeten ikinci sınıflama olan yakın anlamlar içeren unsurlardan teşekkül eden yapılar konusunda daha dikkatli olunması gerekmektedir. Karşıt anlamlı yapıların tespiti ve açıklanması ise oldukça zordur. Tespit edilen yapıların gerçekten zıtlık anlatımı taşıyıp taşımadığı dikkatle incelenmelidir. Bu itibarla, yapılan bu çalışmada, yazıt ve el yazmalarında geçen zıt anlamlı ikilemeler anlam ve yapısal açıdan derinlemesine incelenmiştir. Yapılan değerlendirmelerde, ikileme tanımlamalarının eksik yönleri bir kez daha görülmüştür. Bu çalışma üzerinden de anlaşılacağı üzere, ikilemelerin art arda sıralanma zorunluluğu yoktur ve unsurlar arasına farklı tür ve görevlerde sözcükler girebilmektedir. Ayrıca bir başka tanım eksikliğini işaret eden konu da ikileme unsurları arasında ses benzerliği olma zorunluluğudur. Yapılan incelemede böyle bir gerekliliğin olmadığı da anlaşılmıştır. Bu tespitler, aşağıda verilecek tablolar yardımıyla daha açık bir biçimde görülecektir.

Zıt anlamlı yapıların tasnifteki yerlerinin netleştirilebilmesi adına yapılan yapısal ve anlamsal çözümlemeler neticesinde, söz konusu yapıların sınıfland1rılmasında iki farklı süzgeç olduğu anlaşılmıştır. Sınıflama ölçütü olarak kullanılabilecek ilk önermede, ikilemeyi oluşturan unsurların ayrı ayrı anlamları arasındaki zıtlık ilgisine bakılabilir. Buradaki dayanak, evrende bazı kavramların zıddıyla var olduğu gerçeğidir. Gece ile gündüz, siyah ile beyaz, az ile çok, zengin ile fakir, yaş ile kuru kavramları arasında doğal olarak karşıtllı ilgisi bulunmaktadır. Bu süzgeç kullanılarak yapılacak bir sınıflamada, ikileme yapılarına karşılık vermekte de bir sorun yoktur. Sözgelimi tün kün ikilemesi için 'gece gündüz' kar- 


\section{$J(\Theta)$}

şılığının verilmesi uygundur. İkilemenin kazandığı genel anlam elbette ki bu s1nıflama ölçütünde göz ardı edilmiş olmaktadır. Yapılan incelemede, kimi ikilemelerin karşıladı ̆̆ derin anlatımlarda zıtlık anlamı bulunmamaktadır. Buna karşın yapıların kazandığı zıtlık taşımayan anlamların varlığı, bu ikilemelerin birbirinin karşıtı olan sözcüklerle kurulduğu gerçeğini değiştirmemektedir. Bu yöntemde, ikilemeler için verilecek doğrudan unsurların anlamlarının yan yana getirilmesiyle oluşturulan karşıllklardan sonra, o ikilemelerin bağlam içerisindeki yerinin verilmesi yerinde olacaktır. Böylece tek bir ikilemenin, kazandığı farklı anlamlar rahatlıkla görülebilecektir. Bu ilk yöntem rahatlıkla eski Uygur ve Karahanlı Türkçesi metinlerinde geçen karşıt anlamlı ikilemeler için de uygulanabilir.

İkinci sınıflama ölçütünde ise ikileme unsurları arasındaki anlam ilgisine göre değil ikilemenin kazandığı genel ve çoğu zaman derin anlama göre tasnif yapılabilir. Bu durumda, ikilemelerin her tanıklaması için ayrı bir değerlendirme yapılması gerekmektedir. Tek bir yapı için ayrıntılı açıklamalar da ayrıca zorunlu olacaktır. Bu zorunluluktan başka, ikilemelerin kazandığı anlama odaklanmak gerekeceğinden, unsurlar arasındaki anlam ilgisi göz ardı edilmiş olacaktır. Örneğin tün küntüz ikilemesinin tanıklamalarından biri eş anlamlı ikilemeler tasnifi içerisinde 'süreklilik, devamlılık' karşıllğıyla; diğer bir tanıklamada ise zıt anlamlı ikilemeler tasnifi içerisinde 'gece gündüz' karşıllğıyla verilmesi gerekecektir.

İkilemelerin derinlemesine incelenmesinin, eski Türkçenin anlam dünyasına diğer bir katkısı ise özellikle sık tanıklanmayan bazı sözcüklerin anlaşılması üzerinedir. Anlamı açık olarak kestirilemeyen veya farklı/yanlış yorumlanan bir sözcük, ikileme yapısı içerisinde, ikilemeyi oluşturan diğer unsurlardan hareketle daha iyi anlaşılabilmektedir. Nitekim bu yazının kimi bölümlerinde tam da bu açıdan örnek teşkil edecek durumlar ortaya çıkmıştır. Birbirinin karşıt anlamlısı olan sözcüklerle kurulmuş yapıların derinlemesine incelenmesi, bazı sözcüklerin anlam dünyasına ışık tutma imkânını sağlamıştır.

Eski Türk yazısıyla yazılmış yazıt ve el yazmalarında geçen zıt anlamlı ikilemeler üzerine yapılan bu incelemede ortaya çıkan sonuçlar, aşağıda tablolar hâlinde verilmiştir: 


\begin{tabular}{||c||c||}
\hline \hline Ad Soylu Sözcüklerle Kurulanlar & Eylemlerle Kurulanlar \\
\hline \hline açsık tosık & at- tut- \\
\hline \hline antlig antsız & ér- bar- \\
\hline \hline az üküş & kon- köç- \\
\hline \hline bilir bilmez & köçür- kontur- \\
\hline \hline çıgañ bay & \\
\hline \hline ilgerü kurıgaru & \\
\hline \hline körür körmez & \\
\hline \hline kün tugsuk kün batsık & \\
\hline \hline kün tün & \\
\hline \hline ot suw & \\
\hline \hline tegri yér & \\
\hline \hline tün kün & \\
\hline \hline tün küntüz & \\
\hline \hline tünle küntüz & \\
\hline \hline tünli künli & \\
\hline \hline ulug kiçig & \\
\hline \hline ürün kara & \\
\hline \hline yalay tonlug & \\
yarın kéçe & \\
\hline yér teyri & \\
\hline \hline
\end{tabular}

Tablo I

Sözcük Türü Açısından Zıt Anlamlı İkilemeler

\begin{tabular}{||c||c||c||}
\hline $\begin{array}{c}\text { Basit Sözcüklerden } \\
\text { Oluşanlar }\end{array}$ & $\begin{array}{c}\text { Türemiş Sözcüklerden } \\
\text { Oluşanlar }\end{array}$ & $\begin{array}{c}\text { Biri Basit Diğeri Türemiş } \\
\text { Sözcükten Oluşanlar }\end{array}$ \\
\hline \hline at- tut- & açsık tosık & tün küntüz \\
\hline \hline az üküşs & antlıg antsız & yalan tonlug \\
\hline \hline çıgañ bay & bilir bilmez & \\
\hline \hline ér- bar- & ilgerü kurıgaru & \\
\hline \hline kon- köç- & köçür- kontur- & \\
\hline \hline kün tün & körür körmez & \\
\hline \hline ot suw & kün tugsuk kün batsık & \\
\hline teyri yér & tünle küntüz & \\
\hline
\end{tabular}




\section{J(G}

\begin{tabular}{|c|c|c|}
\hline tün kün & tünli künli & \\
\hline ulug kiçig & yarın kéçe & \\
\hline ürün kara & & \\
\hline yér teyri & & \\
\hline
\end{tabular}

Tablo II

Sözcük Yapısı Açısından Zıt Anlamlı İkilemeler

\begin{tabular}{|c||c||}
\hline Ses Benzerliği Olanlar & Ses Benzerliği Olmayanlar \\
\hline \hline açsık tosık & az üküş \\
\hline \hline antlıg antsız & ot suw $^{12}$ \\
\hline \hline at- tut- & ürün kara \\
\hline \hline bilir bilmez & yalan tonlug ${ }^{13}$ \\
\hline \hline çıañ bay & yarın kéçe \\
\hline \hline ér- bar- & \\
\hline \hline ilgerü kurıgaru & \\
\hline \hline kon- köç- & \\
\hline \hline köçür- kontur- & \\
\hline \hline körür körmez & \\
\hline \hline kün tugsuk kün batsık & \\
\hline \hline kün tün & \\
\hline \hline tejri yér & \\
\hline \hline tün kün & \\
\hline \hline tün küntüz & \\
\hline \hline tünle küntüz & \\
\hline \hline tünli künli & \\
\hline \hline ulug kiçig & \\
\hline yér teyri & \\
\hline \hline
\end{tabular}

Tablo III

Ses Benzerliği Açısından Zıt Anlamlı İkilemeler

${ }^{12}$ Ot suw ikilemesinin unsurları birbirine yakın sesleri içermektedir. Bu ikilemede doğrudan olmasa da dolaylı olarak özellikle telaffuzda /t/ ve /s/ sesleri üzerinden bir uyum sezilmektedir.

13 Yalan tonlug ikilemesinin ilk unsurunun son hecesi ile ikinci unsurunun ilk hecesi arasında, telaffuzda bir ses uyumu bulunmaktadır. Bu açıdan bu ikilemede de ses benzerliği dolaylı olarak vardır. 


\section{J(৫)}

\section{Kısaltmalar}

$\mathrm{BK}=$ Bilge Kagan yazıtı.

$\mathrm{D}=$ doğu

$\mathrm{ED}=$ Clauson 1972

$G=$ güney.

$\mathrm{IB}=$ Irk Bitig.

$\mathrm{K}=$ kuzey .

KT = Köl Tigin yazıtı.

$\mathrm{O}=$ Ongi yazıtı.

ŞU = Şine Usu yazit 1.

$\mathrm{T}=$ Tonyukuk yazıtı.

\section{Kaynakça}

AĞAKAY, M. A. (1953a). “íkizlemeler Üzerine I”, Türk Dili, 16: 189-191.

AĞAKAY, M. A. (1953b). “íkizlemeler Üzerine II”, Türk Dili, 17: 268-271.

AĞAKAY, M. A. (1954). “Türkçede Kelime Koşmaları”, Türk Dili Araştırmaları Yıllığ1 Belleten 1954: 97-104.

AĞCA, F. (2015). “Eski Türkçe kö:k teyri ve kö:k kalık İkilemeleri Üzerine”, Türkbilig, 30: 201-221.

AĞCA, F. (2015). “Eski Uygurcada İştikaklı İkilemeler”, Alkış Bitigi Kemal Eraslan Armağanı, Ed. B. GüL, Ankara: Türk Kültürünü Araştırma Enstitüsü Yayınları: 17-30.

AĞCA, F. (2017). “Çokluk İfadesi Olarak Eski Uygurca talım taşım Eş Çifti”, IX. Uluslararası Dünya Dili Türkçe Sempozyumu (İnönü Üniversitesi, 02-04 Kasım 2017, Malatya). [Yayımlanmamış Bildiri]

AKTAN, B. (2008). “Divanü Lûgati't-Türk'ün Söz Varlığında Yer Alan İkilemeler”, Selçuk Üniversitesi Türkiyat Araştırmaları Dergisi, 28: 1-12.

AKYALçıN, N. (2007). Türkçe İkilemeler Sözlüğü, Ankara: Anı.

Alimov, R. (2014). Tanrı Dağı Yazıtları, Eski Türk Runik Yazıtları Üzerine Bir İnceleme, Konya: Kömen. 


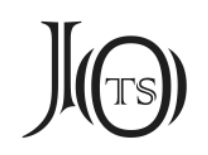

ARAT, R. R. (1979). Kutadgu Bilig I Metin, Ankara: Türk Dil Kurumu Yayınları.

ARAT, R. R. (2006). Edib Ahmed B. Mahmud Yükneki, Atabetü'l-Hakayık, Ankara: Türk Dil Kurumu Yayınları.

ATA, A. (2004). Türkçe İlk Kur'an Tercümesi (Rylands Nüshası, Karahanlı Türkçesi Giriş-Metin-Notlar-Dizin), Ankara: Türk Dil Kurumu Yayınları.

AYdin, E. \& A. KARAMAN (2019), "Eski Türk Yazıt ve El Yazmalarında İkilemeler", Journal of Old Turkic Studies, 3/2: 259-286.

AYdin, E. (1997). “Orhon Yazıtlarında Hendiadyoinler”, Türk Dili, 577: 417-421.

Aydin, E. (2013). “Olon-Nuur/Galuut (Moğolistan) Yazıtı Üzerine Notlar”, Bengü Belak, Ahmet Bican ERCILASUN Armağanı, Ed. B. GüL, Türk Kültürünü Araştırma Enstitüsü Yayınları, Ankara: 123-130.

AYdın, E. (2017). Orhon Yazıtları Köl Tegin, Bilge Kağan, Tonyukuk, Ongi, Küli Çor, İstanbul: Bilge Kültür Sanat.

AYdin, E. (2018). Uygur Yazıtları, İstanbul: Bilge Kültür Sanat.

AYdin, E. (2019). Sibirya'da Türk İzleri, Yenisey Yazıtları, İstanbul: Kronik Kitap.

BANG, W.\& A. vON GABAIN (1929). Analytischer Index zu den fünf ersten Stücken der Türkischen Turfan-Texte, Berlin: ABAW.

BANG, W.vd. (1934). Türkische Turfan Texte VI, Berlin: ABAW.

BARUTÇU-ÖzÖNDER, S. (1998). "Yenisey Kitabeleri ve Yer-Sular”, Journal of Turkish Studies, 22: 171-184.

BASKAKOV, N. A. \& T. M. ToşçAKova (1947). Oyrotsko-Ruskiy Slovar, okolo 10000 slov, Moskova: OGIZ.

BozoK, E. (2018). "Yazıtlarda Geçen ıda taşda İfadesinin Türkiye Türkçesinde ve Ağılardaki Karşılıkları”, Zeitschrift für die Welt der Türken, 10/3: 98-108.

CAFERoĞLu, A. (2015). Eski Uygur Türkçesi Sözlüğü, Ankara: Türk Dil Kurumu Yayınları.

Clauson, Sir G. (1972). An Etymological Dictionary of Pre-Thirteenth Century Turkish, Oxford: Oxford University Press.

ÇAĞATAY, S. (1944). "Uygurcadaki Hendiadyoinler”, Ankara Üniversitesi Dil ve Tarih-Coğrafya Fakültesi Dergisi, 1: 97-144. 


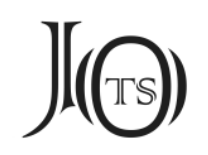

ElmaLI, M. (2016). Daśakarmapathāvadānamālā (Giriş-Metin-Çeviri-Notlar-DizinTıpkıbaskı), Ankara: Türk Dil Kurumu Yayınları.

ERCilasun, A. B. \& Z. AKKoYUnLu (2015). Kâşgarlı Mahmud Dîvânu Lugâti’t-Türk (Giriş-Metin-Çeviri-Notlar-Dizin), 2. Baskı, Ankara: Türk Dil Kurumu Yayınları.

ERDEM, M. D. (2005). Harezm Türkçesinde İkilemeler ve Yinelemeler Üzerine, Bilig, 33: $189-225$.

FoY, K. (1899). "Studien zur Osmanichen Syntax, das Hendiadyoin und die Wortfolge ana baba", Mitteilungen des Seminars für Orientalische Sprachen, 2/2: 105-136.

Gabain, A. von. \& T. Kowalski (1959). Türkische Turfantexte X, das Avadāna des Dämons Ātavaka, Berlin.

Hamilton, J. R. (1998). Budacı İyi ve Kötü Kalpli Prens Masalının Uygurcası: Kalyāṇaṃkara ve Pāpaṃkara, Çev. E. KoRKUT \& İ. BỉRKAN, Ankara: Simurg.

HaTipoĞLu, V. (1981). Türkçede İkilemeler, 2. Baskı, Ankara: Türk Dil Kurumu Yayınları.

HiRí, E. (2018). “Türkçede Tekrarlı Yapı Sınıfları”, Türkiyat Mecmuası, 28/2: 3765.

Karaman, A. (2019). "Eski Türkçede Az Sesteş Kökü Üzerine”, Çukurova Üniversitesi Türkoloji Araştırmaları Dergisi, 4/1:13-34.

KaRAMAN, A. (2019). “Yenisey Yazıtlarında Geçen adrıl- seçlin- İkilemesi Üzerine”, Türk Dili Araştırmaları Yıllı̆̆ı Belleten, 67: 7-26.

Kargi-Ölmez, Z. (1997). “Kutadgu Bilig'de İkilemeler (1)”, Türk Dilleri Araştırmalar1, 7: 19-40.

Kargi-Ölmez, Z. (1998). “Kutadgu Bilig'de İkilemeler (2)”, Bahşi Ögdisi, 60. Doğum Yılı Dolayısıyla Klaus RöHRBORN Armağanı, Eds. M. ÖLMEZ \& J. P. LAUT, Simurg, İstanbulFreiburg: 237-234.

KAYA, C. (1994). Uygurca Altun Yaruk, Giriş, Metin ve Dizin, Ankara: Türk Dil Kurumu Yayınları.

Kormuşin, I. vd. (2016). Yenisey-Altay-Kırgızistan Yazıtları ve Kâğıda Yazılı Runik Belgeler, Ankara: BilgeSu Yayıncilık. 


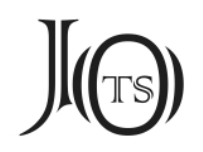

KöK, A. (2004). Karahanlı Türkçesi Satır-Arası Kur'an Tercümesi (Tiem 73 1v 235v/2) Giriş-İnceleme-Metin-Dizin, Ankara Üniversitesi, Sosyal Bilimler Enstitüsü, Ankara. [Yayımlanmamış Doktora Tezi]

LE CoQ, A. A. von (1911). Türkische Manichaica aus Chotscho I, Berlin (AKPAW. Phil.-hist. Cl. 1911, Anhang: Abhandlungen nicht zur Akademie gehöriger Gelehrter. 6).

Malov, S. Ye. (1952). Yeniseyskaya pis'mennost' Tyurkov, textı i perevod1, Moskova-Leningrad.

ORKUN, H. N. (2011). Eski Türk Yazıtları. Ankara: Türk Dil Kurumu Yayınları.

ÖLmEZ, M. (1998). “Eski Uygurca odug sak İkilemesi Üzerine”, Türk Dilleri Araştırmalar1, 8: 35-47.

Ölmez, M. (2017). “Eski Uygurca İkilemeler Üzerine”, Türk Dili Araştırmaları Yı1lığı Belleten, 65-2: 243-311.

RouX, J. P. (2011), Eski Türk Mitolojisi, Çev. M. Y. SAĞLAM, Ankara: BilgeSu Yayınc1lik.

Rozental, D. \& M. A. Telenkova (1976). Slovar Spravoçnik, Lingvistiçeskih Terminov, Moskova: Prosveşçeniye.

RÖHRBORN, K. (1977). Uigurisches Wörterbuch. Sprachmaterial der vorislamischen türkischen Texte aus Zentralasien I: a-agrıg, Wiesbaden: Franz Steiner Verlag.

RöHRBORN, K. (1991). Die alttürkische Xuanzang-Biographie VII, Nach der Handschrift von Paris, Peking und St. Petersburg sowie nach dem Transkript von Annemarie v. Gabain ediert, übersetzt und kommentiert, Wiesbaden: Harrassowitz Verlag.

SEV, G. (2004). “Divanü Lûgati't-Türk’te İkilemeler”, Türk Dili, 634: 497-510.

SeYidov, M. A. (1996). "Eski Türk Kitabelerindeki Yer-Sub Meselesi”, Çev. S. GöMEÇ, Ankara Üniversitesi Dil ve Tarih-Coğrafya Fakültesi Tarih Araştırmaları Dergisi, 18/29: 259-265.

ŞEN, S. (2002). Eski Uygur Türkçesinde İkilemeler, Ondokuz Mayıs Üniversitesi, Sosyal Bilimler Enstitüsü, Samsun. [Yayımlanmamış Yüksek Lisans Tezi]

ŞEN, S. (2015). “Tunyukuk Yazıtındaki ıda taşta İkilemesi Üzerine”, Dil Araştırmalar1, 17: 95-102.

ŞiRiN, H. (2016). Eski Türk Yazıtları Söz Varlığı İncelemesi, Ankara: Türk Dil Kurumu Yayınları. 


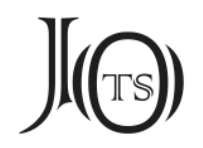

ŞiRiN, H. (2019). Köl Tegin Yazıtı (Notlar), İstanbul: Bilge Kültür Sanat.

TAş, İ. (2012). "Kutadgu Bilig'de İkilemeler”, Türk Dili Araştırmaları Yılllı̆ı Belleten, 60/2: 43-95.

TeKin, Ş. (1980). Maitrisimit Nom Bitig, die uigurische Übersetzung eines Werkes der buddhistischen Vaibhāșika-Schule, 1. Teil: Transliteration, Übersetzung, Anmerkungen, Berliner Turfantexte: 9, Berlin: Akademie Verlag.

TEKin, Ş. (1993). Uygurca Metinler I, Kuanşi İm Pusar (Ses İşiten İlâh), Ankara: Türk Dil Kurumu Yayınları.

TiвiKova, L. N. vd. (2012). Katalog Drevnetyurkskih Runiçeskih Pamyatnikov, Gorno-Altaysk: Gorno-Altaysk Gosudarstvenniy Universitet.

ToPRAK, F. (2005). “Harezm Türkçesinde İkilemeler”, Türk Dünyası İncelemeleri Dergisi, 5/2:277-292.

TunA, O. N. (1983). “Türkçenin Sayıca Eş Heceli İkilemelerinde Sıralama Kuralları ve Tabiî Bir Ünsüz Dizisi”, Türk Dili Araştırmaları Y1llığı Belleten 1982-1983: 163-228.

UçAR, E. (2019). "Orhun Yazıtlarındaki Er- Bar- İkilemesi Üzerine, Journal of old Turkic Studies, 3/2: 471-501.

ÜNLÜ, S. (2004). Karahanlı Türkçesi Satır-Arası Kur'an Tercümesi (Tiem 235v/3 450r7) Giriş-İnceleme-Metin-Analitik Dizin, Hacettepe Üniversitesi, Sosyal Bilimler Enstitüsü, Ankara. [Yayımlanmamış Doktora Tezi]

ÜstÜNovA, K. (1998). Dede Korkut Destanlarında Aralıklı İkilemeler, Türk Dili, 557: 464-470.

WiLKENS, J. (2007). Das Buch von der Sündentilgung, Edition des alttürkisch-buddhistischen Kšanti Kilguluk Nom Bitig, Berliner Turfantexte XXV, Turnhout (Belgium): Brepols Publishers.

YILDIRIM, F. (2017). Irk Bitig ve Orhon Yazılı Metinlerin Dili, Ankara: Türk Dil Kurumu Yayinları.

ZIEME, P. (1985). Buddhistische Stabreimdichtungen der Uiguren, Berliner Turfantexte XIII, Berlin: Akademie Verlag. 